\title{
Active Positioning of Vent Larvae at a Mid-Ocean Ridge
}

Mullineaux, L.S. ${ }^{a *}$, D.J. McGillicuddy Jr. ${ }^{b}$, S.W. Mills ${ }^{a}$, V. K. Kosnyrev ${ }^{b}$, A.M. Thurnherr ${ }^{c}$, J.R. Ledwell $^{b}$, J.W. Lavelle ${ }^{d}$

a Biology Department, Woods Hole Oceanographic Institution Woods Hole, MA 02543, United States

${ }^{b}$ Department of Applied Ocean Physics and Engineering, Woods Hole Oceanographic Institution, Woods Hole, MA 02543, United States

' Division of Ocean and Climate Physics, Lamont-Doherty Earth Observatory, Palisades, NY 10964-8000, United States

d NOAA/Pacific Marine Environmental Laboratory, Seattle, WA 98115, United States

*Corresponding author: Imullineaux@whoi.edu, phone 508 289-2898; fax 508 457-2134

\begin{abstract}
The vertical position of larvae of vent species above a mid-ocean ridge potentially has a strong effect on their dispersal. Larvae may be advected upward in the buoyant vent plume, or move as a consequence of their buoyancy or active swimming. Alternatively, they may be retained near bottom by the topography of the axial trough, or by downward swimming. At vents near $9^{\circ} 50^{\prime} \mathrm{N}$ on the axis of the East Pacific Rise, evidence for active larval positioning was detected in a comparison between field observations of larvae in the plankton in 2006 and 2007 and distributions of non-swimming larvae in a two-dimensional bio-physical model. In the field, few vent larvae were collected at the level of the neutrally buoyant plume ( $75 \mathrm{~m}$ above bottom); their relative abundances at that height were much lower than those of simulated larvae from a near-bottom release in the model. This discrepancy was observed for many vent species, particularly gastropods, suggesting that they may actively remain near bottom by
\end{abstract}


sinking or swimming downward. Near the seafloor, larval abundance decreased from the ridge axis to 1000 m off axis much more strongly in the observations than in the simulations, again pointing to behavior as a potential regulator of larval transport. We suspect that transport off axis was reduced by downward-moving behavior, which positioned larvae into locations where they were isolated from cross-ridge currents by seafloor topography, such as the walls of the axial valley - which are not resolved in the model. Cross-ridge gradients in larval abundance varied between gastropods and polychaetes, indicating that behavior may vary between taxonomic groups, and possibly between species. These results suggest that behaviorally mediated retention of vent larvae may be common, even for species that have a long planktonic larval duration and are capable of long-distance dispersal.

Key Words: Hydrothermal springs, Deep water, Larvae, Mid-ocean ridges 


\section{Introduction}

Deep-sea hydrothermal vents are oases of productive and unusual faunal communities that rely on microbial chemosynthesis as the base of the food web. Most vent invertebrates are capable of moving from one vent to another only in a planktonic larval stage. This mobile stage is particularly important because vent habitats are transient, sometimes on time scales as short as decades. In regions where vent fields are disturbed frequently, larval dispersal is essential for regional persistence of a population. Larval retention at a natal site, however, may be necessary to sustain a local robust population. Metacommunity theory emphasizes the importance of this balance between retention and dispersal in shaping patterns of species diversity and distributions (Holyoak et al 2005), particularly in disturbed systems like vents (Neubert et al. 2006). Larval culturing studies have revealed a potential for long distance transport in vent species (Epifanio et al. 1999; Marsh et al. 2001; Watanabe et al. 2004; Hamasaki et al. 2010; Miyake et al. 2010), but long-distance dispersal events may be rare. Larval abundances tend to be greater near vents than away from them (Metaxas 2004; Mullineaux et al. 2005), and most of the recruitment into an established vent appears to be from nearby populations (Adams and Mullineaux 2008). Nevertheless, colonization by larvae dispersing hundreds of kilometers has been observed, on occasion, in the field (Mullineaux et al. 2010). These studies indicate that both long-distance dispersal and larval retention are possible at vents, but leave unresolved the questions of how often, and by what mechanism, the long-distance events occur.

Field studies indicate that transport in deep currents plays an important role in vent larval dispersal (Adams and Mullineaux, 2008; Adams et al. 2011), but numerous coastal studies show 
that vertical larval swimming behavior can alter transport trajectories and speeds (Dekshenieks et al. 1996; North et al. 2008; Cowen and Sponaugle 2009), especially in sheared flows, such as those observed above mid-ocean ridges (Cannon and Pashinski 1997; Thurnherr et al. 2011). Vent larvae may move vertically by entrainment into, and advection in, the buoyant vent plume (Kim et al. 1994), or as a consequence of their buoyancy or swimming behaviors. The potential for larval entrainment is substantial, as field measurements show that roughly $10 \%$ of tracer released near bottom became entrained into the plume of a nearby vent (Jackson et al. 2010). In a biophysical model of vent larval transport along an axially symmetric ridge, McGillicuddy et al. (2010) demonstrated a strong effect of larval vertical position on dispersal away from the ridge axis. In the model, numerical larvae were released at five heights between 10 and $225 \mathrm{~m}$ above bottom. Lateral transport distance of these larvae decreased systematically with height above bottom because individuals rising $100 \mathrm{~m}$ or more were less influenced by topographically intensified currents near the bottom. A surprising consequence of transport in these sheared currents was that larvae released near the seafloor appeared less likely to recolonize their natal vent than those released at the level of the neutrally buoyant plume.

Our main objective in the present study is to determine whether field distributions of vent larvae show evidence for active vertical positioning, and to evaluate how this behavior may affect their dispersal or retention at vents. We compare distributions of vent larvae collected in plankton samples near $9^{\circ} 50^{\prime} \mathrm{N}$ along the East Pacific Rise (EPR) to positions of neutrally buoyant larvae in simulations using the same hydrodynamic configuration as the model in McGillicuddy et al. (2010). The comparisons evaluate differences in abundance vertically on a scale of $\sim 100$ $\mathrm{m}$ (near bottom and at plume level), and laterally on the scale of 100 to $1000 \mathrm{~m}$ off axis. We 
use multiple species to look for individualized behaviors and to explore whether related taxa behave similarly. We also compare vent larval distributions to those of the strongly swimming vent amphipod, Halice hesmonectes, which is known to form swarms and hold position in active vent effluent (Kaartvedt et al. 1994), and to a common non-vent barnacle cyprid larva. We hypothesize that larvae of some vent species will aggregate more tightly to the ridge crest (i.e., their source vent) than simulated neutral 'larvae', and that the degree of straying from the vent, both vertically and cross-ridge, will be a function of swimming ability (with strong swimmers holding position at the vent). We expect the distribution of non-vent species to show no aggregation at the ridge crest. The $9^{\circ}-10^{\circ} \mathrm{N}$ segment of the EPR is a good model system for this study because the geological and hydrodynamic settings (a linear ridge crest with axial valley and anticyclonically sheared boundary currents; Thurnherr et al. 2011) are common features of seafloor spreading centers globally.

\section{Methods}

\subsection{Field collections}

Specimens were collected in high-volume water filtration systems (McLane WTS 6-1-142LV), fitted with a large (50 L min-1) pump head and a $63 \mu \mathrm{m}$ mesh filter, as in Beaulieu et al. (2009). Pumps were suspended on autonomous moorings at heights of 3 and $75 \mathrm{~m}$ above bottom (mab). The $3 \mathrm{~m}$ height was as close to the seafloor as possible, given the geometry of the mooring release system, and $75 \mathrm{~m}$ was at the lower margin of the neutrally buoyant vent plume. Moorings were lowered from the R/V Atlantis on the hydrographic wire and navigated into position on the seafloor using a relay transponder at the end of the wire that interrogated 
the submersible Alvin's Long Baseline (LBL) net. A wire-mounted Edgetech acoustic release was used to release the mooring from the wire. Pumps were scheduled to run for $24 \mathrm{hrs}$ at a rate of $30 \mathrm{I} \mathrm{min}^{-1}$, starting before noon, local time (LT). This timing allowed for the submersible to survey the on-axis mooring (and reposition if necessary), and for recovery of both moorings mid-day when the ship was not involved in submersible deployment or recovery. An Edgetech acoustic release was used to release each mooring from the seafloor.

Samples were collected on cruises in November 2006 and December 2007 (Table 1). In 2006, three pairs of on/off-axis moorings were deployed. The on-axis moorings were located at three different vents, Riftia Field, Tica, and Ty/lo, all within $1.2 \mathrm{~km}$ of each other. Ty and lo were originally described as two neighboring vents, but only one was apparent when we visited in 2006. The two northern sites, Riftia Field and Tica were situated in a well-defined axial trough with $15 \mathrm{~m}$ high walls, whereas the Ty/lo vent was on a section of the ridge axis without a welldefined trough (Fornari et al. 2012). The off-axis mooring of each pair was positioned $100 \mathrm{~m}$ directly east of each vent. Bottom depth for both on- and off-axis moorings was $2505 \mathrm{~m}$. Offaxis pumps started sampling at 15:30 GMT (09:30 LT) and on-axis ones at 17:30 GMT (11:30 LT). In 2007, four pairs of moorings were deployed. All four on-axis moorings were at Tica, and offaxis moorings were $1000 \mathrm{~m}$ directly east. Bottom depth for the off-axis moorings was $2530 \mathrm{~m}$. On- and off-axis pumps started sampling at 15:30 GMT (except L15 which started at 17:30). Sample volumes for a 24-hr pump period were approximately $40 \mathrm{~m}^{3}$. In a few cases, a pump stopped early, resulting in a smaller sample (Table 2 ), and one pump failed to start (L4, Tica, offaxis, $75 \mathrm{mab})$. 
When plankton samples were recovered on board ship, they were cold (typically $<5^{\circ} \mathrm{C}$ ), and in good condition with some of the specimens still alive. Samples were placed immediately in a $4{ }^{\circ} \mathrm{C}$ cold room, examined briefly under a dissecting microscope, and preserved in $95 \%$ ethanol. In the laboratory, larvae in the samples were sorted under a dissecting microscope and identified to species, or to the lowest taxonomic group possible. Species identifications, and affinities of taxa to vent species, were assigned based on morphology as in Mills et al. (2009). Selected juvenile and adult vent zooplankton were also quantified, as well as non-vent larvae.

Larval abundance patterns in vertical and cross-ridge dimensions were evaluated with a separate 2-way ANOVA (Systat v. 11) for each year, adjusted with a Bonferroni correction when necessary for multiple testing. Abundance data were log transformed, $\ln (x+1)$, to reduce unequal variance. Larvae of individual vent species were the focus of these ANOVAs, but we also analyzed non-larval (amphipod) and non-vent (cyprid) groups for comparison, as well as pooled vent larval groups (all larvae, all gastropods, all polychaetes) to look for overall or taxonspecific patterns.

\subsection{Model simulations}

Larval trajectories were simulated using velocities extracted from a primitive equation model (Lavelle, 2006) implemented in a two-dimensional (cross-ridge, depth) axisymmetric configuration with idealized bathymetry representative of the EPR at $9^{\circ} \mathrm{N}$ (see McGillicuddy et al. (2010) for a detailed description). Forcing was deduced from an inverse procedure to minimize the difference in simulated and observed velocities from a current meter deployed 
$175 \mathrm{mab}$ at $9^{\circ} 51^{\prime} \mathrm{N}$ on the ridge axis May-November 1999 . The model predicts mean flows of several $\mathrm{cm} \mathrm{s}^{-1}$ along the ridge flanks that are consistent with observations (McGillicuddy et al. 2010; Lavelle et al. 2010, 2012; Lavelle 2012). Because the model is idealized, and the simulations do not pertain to the exact time period of the plankton pump deployments, we do not expect exact correspondence between the predictions and the observations of larval abundance. However, analysis of currents measured at this same site from 2006 to 2007 (Thurnherr et al. 2011), covering the larval sampling intervals, show they fall within the envelope of variability observed in the 1999 time series and the associated simulation of that record (McGillicuddy et al. 2010, see especially Fig. 4). Therefore we do expect some time periods during the seven-month simulation to be representative of the hydrodynamic conditions during the pump deployments. As such, qualitative comparisons between the simulated and observed larval abundances are illustrative, especially of patterns that are consistent over time.

Three-dimensional trajectories of numerical larvae were computed assuming homogeneity in currents in the along-ridge direction. Passive particles were released at 10 mab (to mimic a bottom source) and 75 mab (to mimic entrainment in the buoyant plume) every 12 minutes above the ridge axis, and tracked with an algorithm described in Werner et al. (1993) and Blanton (1995). Selection of 10 mab for the bottom source (rather than 1 mab where most larval release may occur) was arbitrary, but unlikely to affect results, as the vertical resolution of the hydrodynamic model was $12.5 \mathrm{~m}$ at the ridge crest. Simulated plankton pumps were located at $3 \mathrm{mab}$ and $75 \mathrm{mab}$ at the ridge crest and $1000 \mathrm{~m}$ east and west of the axis. Larvae were assumed to have an embryonic interval of 1.5 days (a typical time to set the initial larval 
shell in molluscs; Strathmann 1987) during which they were immune to capture by the simulated pumps. Larvae in this stage of development are not identifiable to species in our field samples and are not included in field counts. Given current speeds of several $\mathrm{cm} \mathrm{s}^{-1}$, the embryonic interval provides ample time for the larvae to escape the grid cell from which they were released, which coincides with the grid cell of the near-bottom, on-axis, plankton pump. After the embryonic period, larvae were captured by the pumps with $100 \%$ efficiency if they entered the grid cell in which the plankton pumps resided. If a larva was not captured within 30 days, it was assumed to have died.

\section{Results}

\subsection{Field distributions}

A diverse assemblage of larvae of vent taxa was collected in pump samples, including 23 gastropod species or genera, two bivalve species, nine polychaete species or groups, and two crustacean species (Table 2). For comparison, we include three non-larval vent taxa known to be strong swimmers (amphipod adults, caridean shrimp juveniles and leptostracan juveniles and adults), and a larval barnacle (cyprid) of non-vent origin. A complete list of taxa, including larvae that were not identifiable to genus, is in Supplemental Table S1. Species composition of polychaetes was similar between 2006 and 2007 samples, but several gastropod and crustacean species that were abundant in 2006 were absent or notably less common in 2007. Many of these, including the gastropods Ctenopelta porifera and Gorgoleptis emarginatus, and the crabs Bythograea thermydron and Bythograea microps, were pioneer species that had colonized in 
high numbers after a seafloor eruption in early 2006 (Mullineaux et al. 2010), but had decreased in numbers afterward (Mullineaux et al. 2012).

The dominant abundance pattern in vent larvae (all taxa pooled) was a striking decrease in numbers with height above bottom (Fig. 1). This decrease was significant $(P<0.001$; Table 3$)$ and particularly prominent on-axis where abundances were roughly 2 orders of magnitude lower at 75 mab than at 3 mab in both 2006 and 2007. Larval numbers were consistently lower off-axis than on, but the difference was significant only in 2007 when the off-axis distance was $1000 \mathrm{~m}$. The vertical gradient in abundance at $1000 \mathrm{~m}$ off axis was much weaker than on axis (resulting in a significant interaction between height and distance effects; Table 3) and at $100 \mathrm{~m}$ off axis.

Gastropods were the most numerous larval group and hence showed similar abundance patterns to the pooled larval taxa: a striking and significant decrease in abundance with height off bottom and a consistent decrease in abundance with distance off axis that was significant at $1000 \mathrm{~m}$ but not $100 \mathrm{~m}$ (Fig. 2; Table 3). In some cases, standard deviations at a particular height and distance were large, indicating substantial variation between sampling days. Examination of day-to-day variation in abundance patterns of the most abundant gastropod genus, Lepetodrilus spp., showed that both the on-axis abundance, and the proportional decrease off axis, varied substantially between days (Fig. 3). This variation was most notable in 2006 , although the samples were collected at different sites so this may also reflect spatial variability. The near-bottom pattern at Ty/lo (moorings L1 and L2) was anomalous in that onaxis abundance was not substantially greater than off-axis values. This anomaly at Ty/lo was observed in several other common gastropod species, Gorgoleptis emarginatus, Peltospira sp., 
and Sutilizona theca (Table 2; Supplemental Figs S1-S3) a few of which (Lepetodrilus spp. and S. theca) were more abundant off axis than on. No similar anomalous pattern was observed in 2007 when all samples were collected $1000 \mathrm{~m}$ off axis at Tica vent. In general, the gastropod abundance gradients (vertical and horizontal) at each particular date and site were qualitatively similar across species, suggesting that time-variant current direction, or topographic differences between sites, influenced all gastropods in the same way.

Polychaetes were similar to gastropods in their significant vertical abundance gradients, but deviated from the general larval patterns by displaying a relatively weak, and non-significant, cross-ridge gradient in 2007 (Fig. 2). Near the bottom (3 mab), the off-axis polychaete abundance was reduced relative to on-axis, but only to $\sim 30 \%$, in contrast to $2 \%$ for gastropods. At plume level (75 mab), off-axis abundance tended to be greater than on, but not significantly (Fig. 2, Table 3). Day-to-day variation in polychaete abundance was high, as demonstrated by Ophryotrocha akessoni (Fig. 4) and other less-numerous taxa (Supplemental Figs. S4-S6). The Ty/lo anomaly was apparent in O. akessoni in 2006, and in chaetosphaerids (Supplemental Fig. S4), but not in nectochaetes or spionids (Supplemental Figs. S5-S6).

The amphipod Halice hesmonectes displayed abundance patterns that were similar to larvae, except near the bottom in 2006 (Fig. 2). In these samples, the decrease from on axis to $100 \mathrm{~m}$ off axis was much weaker than for gastropod or polychaete larvae. This result was surprising because adult amphipods are not generally considered a dispersive phase and we thought they would be less likely to stray off axis than the larvae.

The non-vent cyprid larvae displayed very different patterns than the vent species (Fig. 2). They were not more abundant near bottom than at plume level; instead their abundance at 75 
mab was either similar to (2006) or significantly greater than (2007) values at 3 mab (Table 3). Across the ridge, they tended to decrease in numbers off axis at 3 mab (but not significantly), but showed no decrease at 75 mab.

At plume level (75 mab), vent larvae were scarce (Fig. 1), and most species or groups (29 of 36 taxa) were not represented (Table 2). The few species that were present at this height, however, showed intriguing patterns. On several sample dates, particularly in 2007 , the abundance of gastropods or polychaetes at 75 mab did not show the marked decrease with offaxis distance observed in near bottom samples (Supplemental Figs. S1-S6). In a few cases, e.g., in 2007 for the gastropod Gorgoleptis emarginatus (Supplemental Fig. S1) and the polychaete Ophryotrocha akessoni (Fig. 4), the abundance off axis at 75 mab was greater than on axis, despite the reverse pattern near bottom. The strongly swimming vent amphipods were rarely observed 75 mab. In contrast to these patterns in vent species, the non-vent cyprids occurred predominantly at the 75 mab level.

Abundance variations over short time scales (days) were as great, or greater than, variations between years for many taxa (Figs. 3 - 4, Supplemental Figs. S1-S6). In most gastropods, but only a few polychaetes, the temporal patterns were similar across taxa.

\subsection{Model simulations}

Simulated plankton pump data exhibit high variability in larval capture, with fluctuations not only in the numbers of particles trapped, but also in their cross-ridge and vertical distributions). For the particles released at 10 mab (Fig. 5, left column), there are some cases in which the near-bottom pumps mimic the observed tendency of higher capture rates on axis 
than off axis (May-June, June-July), although the amplitude of the cross-ridge differential is less in the model than the field observations. Surprisingly, the more common pattern is for lower capture rates on axis than off axis, as evidenced by the July-November results. Capture rates are higher west of the ridge than east of the ridge in July-November, but the opposite occurs in May-July. Throughout the simulated time-series of 10 mab releases, aggregate on-axis capture rates at 75 mab are generally lower than at 3 mab, but the vertical gradient is not nearly as large in the model as it is in the observations. Moreover, off-axis capture rates at 75 mab, of particles released at $10 \mathrm{mab}$, are higher than those on-axis-and such a trend occurs only occasionally in the observations.

In contrast to the 10 mab releases, particles released at 75 mab are consistently more likely to be captured on axis than off axis by the pumps located at the release depth (Fig. 5, right column). This finding is consistent with the results reported in McGillicuddy et al. (2010), which indicate that larvae positioned higher in the water column tend to be dispersed less than those closer to the bottom. Rising higher in the water column causes the larvae to be more isolated from the vigorous near-bottom currents that transport fluid in the along-ridge, cross-ridge, and vertical directions. The reduced effect of these benthic flows has a dramatic impact on the fate of particles released at 75 mab. As a consequence of the reduced vertical excursions, very few of the particles are captured by the near-bottom pumps. As a result of the weaker cross-ridge displacement of larvae, the on/off axis gradient in 75 mab capture rate for the 75 mab release is generally larger than for both the near-bottom and 75 mab pump sampling of the 10 mab releases. 
Example particle trajectories illustrate the cross-ridge and along-ridge displacements characteristic of particles captured by the simulated plankton pumps (Fig. 6). These trajectories constitute a small subset of the total number of particles, as only 1-4\% of the particles released are captured by the pumps. Most of the captured particles never travel more than a few km from the release point prior to encountering the pumps (Fig. 6, left panel). However, there are exceptions - in some cases, particles displaced tens of $\mathrm{km}$ from the release site eventually make their way back to be captured by the pumps. The particles are also subject to vertical displacements of hundreds of meters as they are swept back and forth across the ridge (Fig. 6, right panel).

\section{Discussion}

The comparison of field and model results shows that vent larvae were more aggregated at the source release site (near bottom, on axis) than simulated larvae. We had expected this to be the case for at least some species, but were surprised at the intensity of the observed vertical abundance gradient, and the consistency across species. In the model, abundances of bottom-released larvae captured at 75 mab were no less than $\sim 25 \%$ of near-bottom captures, whereas in the field, abundances of vent larvae sampled at 75 mab were typically $<1 \%$. This discrepancy is particularly striking in light of the fact that the model does not explicitly represent the buoyant plume, which would tend to diminish the vertical gradient in larval abundance even further.

A passive tracer released in the axial trough near $9^{\circ} 30^{\prime} \mathrm{N}$ in November 2006 also showed less of a difference between the amount of tracer at plume level and the amount at the level of 
the ridge about 40 days after release (Jackson et al. 2010). The tracer was released in a $1200-\mathrm{m}$ long segment of the EPR occupied by a few diffuse low-temperature vent fields and by a single high-temperature vent. The authors estimated that on the order of $10 \%$ of the tracer ended up in the potential density range of the plume of the high-temperature vent. This experiment adds to the evidence that vent larvae are, by some means, able to stay near the seafloor much more effectively than if they were dynamically passive and neutrally buoyant.

The most likely explanation for the observed rarity of vent larvae at plume level is that many species, particularly gastropods, actively stay near the seafloor by swimming or sinking downward. Such bottom-oriented positioning has been observed in laboratory-reared larvae of vent gastropods (Metaxas, 2011), although not in larvae of vent crustaceans, which tend to move upward after hatching (Miyake et al. 2010). Furthermore, larvae of coastal species are known to move downward in response to chemical or hydrodynamic cues (e.g., Tamburri et al. 1996, Fuchs et al. 2004), as they become competent to settle. Although active behavior is a reasonable explanation for the discrepancy between our field and model results, we acknowledge that the idealized nature of the model, or the limited sample duration of the field collections, might also have contributed. Nevertheless, the magnitude of the differences, and their consistency across multiple intervals in both the field and model, lead us to favor a behavioral explanation.

Near the seafloor, vent larvae were less abundant at a distance of $1000 \mathrm{~m}$ off axis, relative to on axis, than simulated larvae. The cross-ridge gradient predicted by the model is highly variable, and the direction of the gradient is consistent with the observations in two of the six months simulated. These differences are not surprising given that the velocity record used to 
force the model comes from a different time period than that of the pump deployments themselves. Nevertheless, even when the simulated cross-ridge gradient in larval abundance is in the same direction as the observations, its magnitude is far smaller than observed. This discrepancy suggests that larvae are capable of holding position near a vent, even though their typical swimming speeds ( $<0.5 \mathrm{~cm} \mathrm{~s}^{-1}$; Mileikovsky 1973; Chia et al. 1984) are an order of magnitude lower than daily maximal tidal current velocities ( $>5 \mathrm{~cm} \mathrm{~s}^{-1}$; Beaulieu et al. 2009) a few $m$ above bottom in this region. Such swimming behavior may allow the larvae to exploit weaker flows present in near-bottom boundary layers that are not represented in the model. Alternatively, small-scale topography along the ridge axis may effectively trap larvae near their natal site (Mullineaux et al. 2005) - and such topographic details are also not included in the model. Nor does the two-dimensional model include three-dimensional effects associated with complex topography such as the Lamont Seamount Chain, which influences flow and transport in the vicinity of $9^{\circ} 50^{\prime} \mathrm{N}$ (Lavelle et al. 2010; Jackson et al. 2010; Thurnherr et al. 2011). Clearly, a three-dimensional particle-tracking model that incorporates complex topography would be valuable for future quantitative investigations of larval distributions and dispersal along the EPR and elsewhere.

We can evaluate the possible influence of behavior by comparing larval distribution patterns across species. The differences between taxa in the magnitude of the cross-ridge gradient did not correspond to presumed swimming speed. Gastropod larvae are considered weaker swimmers than most polychaete larvae (Mileikovsky 1973), but vent gastropods were not found more frequently than vent polychaetes off axis, at either 100 or $1000 \mathrm{~m}$. This pattern suggests that gastropod larvae are at least as effective as polychaetes at actively holding 
position at a vent. They may respond to vent cues more strongly, or may take advantage of their negatively buoyant shell to stay close to the bottom, protected by seafloor topography from cross-axis currents. The similarity across gastropod species in day-to-day variations in cross-ridge distributions is consistent with the idea that they share a common behavior that results in similar transport. Surprisingly, adult vent amphipods were no more effective than vent gastropod larvae at remaining on axis, again suggesting that behavioral aspects other than swimming speed are responsible for cross-ridge distributions. Non-vent cyprid (barnacle) larvae displayed a vertical gradient opposite to that of vent larvae, as expected for a species not spawned at the ridge. This pattern supports the idea that holding position at a vent is a behavior specific to vent species.

In contrast to the marked and significant reduction in vent larvae observed in the field at $1000 \mathrm{~m}$ off axis, the reduction at $100 \mathrm{~m}$ was much less pronounced, and not significant. This may be due to the magnitude of tidal flows at this location. Data from the moored current meters on the ridge (Thurnherr et al. 2011) indicate that the root-mean-square (rms) crossridge, semidiurnal, tidal displacement at $9^{\circ} 50^{\prime} \mathrm{N}$ is $300 \mathrm{~m}$, so if there were no low-frequency cross-ridge advection, larval measurements taken $100 \mathrm{~m}$ from the ridge crest might be expected to be nearly the same as at the ridge crest. The observation of even a modest reduction in larval abundance at $100 \mathrm{~m}$ off axis is consistent with the idea that larval behavior may be contributing to on-axis retention.

We can evaluate the possible topographic influence on cross-ridge distributions by comparing the larval abundance gradients at $\mathrm{Ty} / \mathrm{lo}$, where the axial trough was shallow and indistinct, to those at Tica and Riftia Field, where the axial trough was relatively narrow and 15 
$m$ deep. All four common gastropod species showed a weaker cross-ridge gradient at Ty/lo than at the other sites. Two of these, Lepetodrilus spp. and Sutilizona theca, were more abundant $100 \mathrm{~m}$ off axis than on axis. Of the four common polychaete groups, two showed a weaker cross-ridge gradient at Ty/lo, but the other two did not. An examination of nearbottom velocities recorded by a bottom-mounted Acoustic Doppler Current Profiler (ADCP) within the well-defined axial trough near $9^{\circ} 30^{\prime} \mathrm{N}$ (Jackson et al. 2010), and by nearby conventional current meters (Thurnherr et al. 2011), shows that velocities at the top of the axial trough are roughly half of velocities higher up in the water column. Cross-ridge velocities within the trough are difficult to measure, but are likely reduced further due to topographic blocking by the steep walls. Observations following the $9^{\circ} 30^{\prime} \mathrm{N}$ tracer release (Jackson et al. 2010), indicate that tracer tends to get retained in the trough and other steeply bounded depressions. We conclude that topography appears to influence cross-ridge larval export from vents, particularly in species that actively remain near bottom, but we caution that the sampling for this analysis was not replicated, and numbers in samples were small for some of the species.

Our results indicate that larvae of vent gastropods, and possibly other vent species, actively remain near the seafloor, a behavior that reduces their off-axis transport, especially when the natal vent site is topographically protected from more vigorous ambient currents. This finding has important implications for vent connectivity because it suggests that retention of gastropods is common, even though species may have long planktonic larval duration and be capable of long-distance dispersal. If long-distance exchanges are rare, the arrival of remote 
species to disturbed or newly opened vent habitat will introduce stochasticity into successional processes and species' distributions.

\section{Acknowledgements}

We gratefully acknowledge the support of NSF grants OCE-0424953 and OCE-0525361, which funded the Larval Dispersal on the Deep East Pacific Rise (LADDER) project. WHOI provided additional support to LSM as an Ocean Life Fellow, to DJM as the Holger Jannasch Chair for Excellence in Oceanography, and to JRL as the Edward W. and Betty J. Scripps Senior Scientist Chair. JWL was supported by the National Oceanic and Atmospheric Administration's (NOAA) Vents Program and by NOAA's Pacific Marine Environmental Laboratory. We appreciate the operations support from the Captain and crew of R/V Atlantis, and the Alvin group, during cruises AT15-12 and AT15-26. Technical and scientific assistance at sea was provided by S. Bayer, S. Beaulieu, I. Garcia Berdeal, X. Guan, B. Guest, B. Hogue, P.R. Jackson, A. Kohli, X. Liang, A. Ruiz-Angulo, N. Stagliçic, C. Strasser, F. Terenzi, B. Walther, and S. Worrilow. A. Warén provided expertise on larval gastropod identification. The study benefited from discussions with Stace Beaulieu and Diane Adams, and the manuscript was improved by comments from three anonymous reviewers. 


\section{References}

Adams, D.K., McGillicuddy, D.J., Zamudio, L., Thurnherr, A.M., Liang, X., Rouxel, O., German, C.R., Mullineaux, L.S., 2011. Surface-generated mesoscale eddies transport deep-sea products from hydrothermal vents. Science 332, 580-583.

Adams, D.K., Mullineaux, L.S., 2008. Supply of gastropod larvae to hydrothermal vents reflects transport from local larval sources. Limnology and Oceanography 53, 1945 - 1955.

Beaulieu, S.E., Mullineaux, L.S., Adams, D.K., Mills, S.W., 2009. Comparison of a sediment trap and plankton pump for time-series sampling of larvae near deep-sea hydrothermal vents. Limnol Oceanogr Methods 7, 235-248.

Blanton, B., 1995. DROG3D: user's manual for three-dimensional drogue tracking on a finite element grid with linear finite elements (see http://www.opnml.unc.edu/Particle_Tracking/part_track.htmIS). Program in Marine Sciences, University of North Carolina, Chapel Hill, NC.

Cannon, G.A., Pashinski, D.J., 1997. Variations in mean currents affecting hydrothermal plumes on the Juan de Fuca Ridge. Journal of Geophysical Research 102 (C11), 24965-24976.

Chia, F.S., Buckland-Nicks, J., Young, C.M., 1984. Locomotion of marine invertebrate larvae: a review. Can. J. Zool. 62, 1205-1222.

Cowen, R.K., Sponaugle, S., 2009. Larval dispersal and marine population connectivity. Annual Review of Marine Science 1, 443-466.

Dekshenieks, M.M., Hofmann, E.E., Klinck, J.M., Powell, E.N., 1996. Modeling the vertical distribution of oyster larvae in response to environmental conditions. Marine Ecology Progress Series 136 (1-3), 97-110. 
Epifanio, C.E., Perovich, G., Dittel, A.L., Cary, S.C., 1999. Development and behavior of megalopa larvae and juveniles of the hydrothermal vent crab Bythograea thermydron. Marine Ecology Progress Series 185, 147-154.

Fuchs, H.L., Mullineaux, L., Solow, A., 2004. Sinking behavior of gastropod larvae (Ilyanassa obsoleta) in turbulence. Limnology and Oceanography 49, 1937-1948.

Fornari, D.J., Von Damm, K.L., Bryce, J.G., Cowen, J.P., Ferrini, V., Fundis, A., Lilley, M.D., Luther, G.W., Mullineaux, L.S., Perfit, M.R., Meana-Prado, M.F., Rubin, K.H., Seyfried, W.E., Shank, T.M., Soule, S.A., Tolstoy, M., White, S.M., 2012. The East Pacific Rise between $9^{\circ} \mathrm{N}$ and $10^{\circ} \mathrm{N}$ : Twenty-five years of integrated, multidisciplinary oceanic spreading center studies. Oceanography 25 (1), 18-43.

Hamasaki, K., Nakajima, K., Tsuchida, S., Kado, R., Kitada, S., 2010. Number and duration of zoeal stages of the hydrothermal vent crab Gandalfus yunohana from laboratory reared specimens. J. Crust. Biol 30 (2), 236-240.

Holyoak, M., Leibold, M.A., Holt, R.D., 2005. Metacommunities: spatial dynamics and ecological communities. The University of Chicago Press, Chicago.

Jackson, P.R., Ledwell, J.R., Thurnherr, A.M., 2010. Dispersion of a tracer on the East Pacific Rise $\left(9^{\circ} \mathrm{N}\right.$ to $\left.10^{\circ} \mathrm{N}\right)$, including the influence of hydrothermal plumes. Deep-Sea Research Part I-Oceanographic Research Papers 57 (1), 37-52.

Kaartvedt, S., Van Dover, C.L., Mullineaux, L.S., Wiebe, P.H., Bollens, S.M., 1994. Amphipods on a deep-sea hydrothermal treadmill. Deep Sea Res I 41, 179-195.

Kim, S.L., Mullineaux, L.S., Helfrich, K.R., 1994. Larval dispersal via entrainment into hydrothermal vent plumes. Journal of Geophysical Research 99, 12,655-612,665. 
Lavelle, J.W., 2006. Flow, hydrography, turbulent mixing, and dissipation at Fieberling Guyot examined with a primitive equation model. J. Geophys. Res. 111 (C07014).

Lavelle, J.W., 2012. On the dynamics of current jets trapped to the flanks of mid-ocean ridges. J. Geophys. Res. 117, C07002.

Lavelle, J.W., Thurnherr, A.M., Ledwell, J.R., McGillicuddy, D.J., Mullineaux, L.S., 2010. Deep ocean circulation and transport where the East Pacific Rise at $9-10^{\circ} \mathrm{N}$ meets the Lamont seamount chain. Journal of Geophysical Research-Oceans 115, C12073.

Lavelle, J.W., Thurnherr, A.M., Mullineaux, L.S., McGillicuddy, D.J., Ledwell, J.R., 2012. The prediction, verification and significance of flank jets at mid-ocean ridges. Oceanography $25,277-283$.

Marsh, A.G., Mullineaux, L.S., Young, C.M., Manahan, D.T., 2001. Larval dispersal potential of the tubeworm Riftia pachyptila at deep-sea hydrothermal vents. Nature 411, 77-80.

McGillicuddy, D.J., Lavelle, W., Thurnherr, A.M., Kosnyrev, V.K., Mullineaux, L.S., 2010. Larval dispersion along an axially symmetric mid-ocean ridge. Deep Sea Res I 57, 880-892.

Metaxas, A., 2004. Spatial and temporal patterns in larval supply at hydrothermal vents in the northeast Pacific Ocean. Limnology and Oceanography 49, 1949-1956.

Metaxas, A., 2011. Spatial patterns of larval abundance at hydrothermal vents on seamounts: evidence for recruitment limitation. Mar Ecol Prog Ser 437, 103-117.

Mileikovsky, S.A., 1973. Speed of active movement of pelagic larvae of marine bottom invertebrates and their ability to regulate their vertical position. Marine Biology 23, 1117. 
Mills, S.W., Beaulieu, S.E., Mullineaux, L.S., 2009. Photographic identification guide to larvae at hydrothermal vents. Woods Hole Oceanog. Inst. Tech. Rept. WHOI-2009-05.

Miyake, H., Kitada, M., Itoh, T., Nemoto, S., Okuyama, Y., Watanabe, H., Tsuchida, S., Inoue, K., Kado, R., Ikeda, S., Nakamura, K., Omata, T., 2010. Larvae of deep-sea chemosynthetic ecosystem animals in captivity. Cahiers De Biologie Marine 51 (4), 441-450.

Mullineaux, L.S., Adams, D.K., Mills, S.W., Beaulieu, S.E., 2010. Larvae from afar colonize deepsea hydrothermal vents after a catastrophic eruption. Proc. Natl. Acad. Sci. 107 (17), 7829-7834.

Mullineaux, L.S., Le Bris, N., Mills, S.W., Henri, P., Bayer, S.R., Secrist, R.G., Siu, N., 2012.

Detecting the influence of initial pioneers on succession at deep-sea vents. Plos One 7. doi:50010.51371/journal.pone.0050015.

Mullineaux, L.S., Mills, S.W., Sweetman, A.K., Beaudreau, A.H., Metaxas, A., Hunt, H.L., 2005. Spatial structure and temporal variation in larval abundance at hydrothermal vents on the East Pacific Rise. Marine Ecology Progress Series 293, 1-16.

Neubert, M.G., Mullineaux, L.S., Hill, M.F., 2006. A metapopulation approach to interpreting diversity at deep-sea hydrothermal vents. In: Kritzer, J.P., Sale, P.F. (Eds.), Marine Metapopulations. Elsevier, London, pp. 321-350.

North, E., Schlag, Z., Hood, R., Li, M., Zhong, L., Gross, T., Kennedy, V., 2008. Vertical swimming behavior influences the dispersal of simulated oyster larvae in a coupled particletracking and hydrodynamic model of Chesapeake Bay. Marine Ecology Progress Series 359, 99-115. 
Strathmann, M.F., 1987. Reproduction and development of marine invertebrates of the northern Pacific coast. University of Washington Press, Seattle.

Tamburri, M., Finelli, C., Wethey, D., Zimmer-Faust, R., 1996. Chemical induction of larval settlement behavior in flow. Biological Bulletin 191 (3), 367-373.

Thurnherr, A.M., Ledwell, J.R., Lavelle, J.W., Mullineaux, L.S., 2011. Hydrography and circulation near the crest of the East Pacific Rise between $9^{\circ}$ and $10^{\circ}$ N. Deep-Sea Research Part I $58(4), 365-376$.

Watanabe, H.K., R; Tsuchida, S; Miyake, H; Kyo, M; Kojima, S, 2004. Larval development and intermoult period of the hydrothermal vent barnacle Neoverruca sp. Journal of the Marine Biological Association of the United Kingdom 84, 743-745.

Werner, F.E., Page, F.H., Lynch, D.R., Loder, J.W., Lough, R.G., Perry, R.I., Greenberg, R.M., Sinclair, M.M., 1993. Influences of mean advection and simple behavior on the distribution of cod and haddock early life stages on Georges Bank. Fisheries Oceanography 2, 43-64. 
Table 1. Location, start date and start time (GMT) for pump samplers on paired on/off axis moorings in 2006 and 2007. Paired samplers operated synoptically except when constrained by ship operations (in 2006) or instrument malfunction (L15).

\begin{tabular}{llll}
\hline Mooring & Site & Start date & Start time \\
& & & \\
\hline L1, L2 & Ty/lo & 1 Nov. 2006 & 17:30, 15:30 \\
L3, L4 & Tica & 5 Nov. 2006 & 17:30, 15:30 \\
L5, L6 & Riftia Field & 8 Nov. 2006 & 17:30, 15:30 \\
L15 & Tica & 18 Nov. 2007 & $17: 30$ \\
L16 & Tica & 17 Nov. 2007 & $15: 30$ \\
L17, L18 & Tica & 21 Nov. 2007 & $15: 30$ \\
L19, L20 & Tica & 25 Nov. 2007 & $15: 30$ \\
L21, L22 & Tica & 29 Nov. 2007 & $15: 30$ \\
\hline
\end{tabular}


Table 2. Abundance (no. per $1000 \mathrm{~m}^{3}$ ) of larvae of vent species in pump samples in 2006 (on and $100 \mathrm{~m}$ off axis) and 2007 (on and $1000 \mathrm{~m}$ off axis) at heights of 3 and $75 \mathrm{~m}$ above bottom (mab). Pumps were located at Riftia Field, Tica and Ty/lo vents. Select juvenile or adult crustaceans, and non-vent larvae (large cyprid) included for comparison. [Note to editors; table is intended to be placed on facing pages] 


\begin{tabular}{|c|c|c|c|c|c|c|c|c|c|c|c|c|}
\hline Date/Height & $2006 /$ & $3 \mathrm{mab}$ & & & & & $2006 /$ & $75 \mathrm{mak}$ & & & & \\
\hline Mooring Number & L1 & L2 & L3 & $\overline{\mathrm{L} 4}$ & L5 & $\overline{L 6}$ & L1 & $\overline{\mathrm{L} 2}$ & L3 & $\overline{\mathrm{L} 5}$ & L6 & \\
\hline Location & Ty/lo & Ty/lo & Tica & Tica & Riftia & Riftia & Ty/lo & Ty/lo & Tica & Riftia & Riftia & \\
\hline Distance off axis (m) & 0 & 100 & 0 & 100 & 0 & 100 & 0 & 100 & 0 & 0 & 100 & \\
\hline Volume $\left(m^{\wedge}-3\right)$ & 41.5 & 41.5 & 41.5 & 41.5 & 41.5 & 40.4 & 33.6 & 33.7 & 32.1 & 39.3 & 41.5 & \\
\hline$\overline{\text { MOLLUSCA - GASTROPODA }}$ & & & & & & & & & & & & \\
\hline Bathymargarites symplector & 0 & 0 & 0 & 0 & 0 & 0 & 0 & 0 & 0 & 0 & $c$ & 0 \\
\hline Clypeosectus delectus & 0 & 0 & 48 & 0 & 48 & 49 & 0 & 0 & 0 & 0 & & 0 \\
\hline Ctenopelta porifera & 25 & 25 & 72 & 0 & 169 & 49 & 0 & 0 & 0 & 0 & & 0 \\
\hline Cyathermia naticoides & 96 & 72 & 25 & 0 & 169 & 0 & 0 & 0 & 0 & 0 & & 0 \\
\hline Echinopelta fistulosa & 25 & 0 & 0 & 0 & 145 & 25 & 30 & 0 & 0 & 0 & & 0 \\
\hline Gorgoleptis emarginatus & 795 & 554 & 1036 & 120 & 2144 & 25 & 59 & 0 & 0 & 0 & & 0 \\
\hline Gorgoleptis spiralis & 72 & 25 & 96 & 0 & 241 & 74 & 0 & 0 & 0 & 0 & & 0 \\
\hline Gorgoleptis sp. 3 & 0 & 0 & 48 & 0 & 25 & 74 & 0 & 0 & 0 & 0 & & 0 \\
\hline Eulepetopsis vitrea & 0 & 0 & 25 & 0 & 25 & 0 & 0 & 0 & 0 & 0 & & 0 \\
\hline Laeviphitus sp. & 120 & 72 & 120 & 25 & 506 & 198 & 0 & 0 & 0 & 0 & & 0 \\
\hline Lepetodrilus spp. & 1952 & 2530 & 5083 & 626 & 8409 & 2571 & 476 & 59 & 9 & 0 & & 0 \\
\hline Lepetodrilus spp. post-larva & 0 & 0 & 25 & 0 & 0 & 0 & 0 & 0 & b & 0 & & 0 \\
\hline Lirapex granularis & 0 & 0 & 48 & 25 & 48 & 49 & 0 & 0 & 0 & 0 & & 0 \\
\hline Melanodrymia aurantiaca & 48 & 0 & 48 & 25 & 72 & 25 & 0 & 0 & 0 & 0 & & 0 \\
\hline Melanodrymia galeronae & 0 & 0 & 0 & 0 & 0 & 0 & 0 & 0 & 0 & 0 & & 0 \\
\hline Neomphalus fretterae & 0 & 0 & 72 & 0 & 72 & 0 & 0 & 0 & 0 & 0 & & 0 \\
\hline Neolepetopsis densata & 0 & 0 & 0 & 0 & 0 & 25 & 0 & 0 & 0 & 0 & & 0 \\
\hline Pachydermia laevis* & 25 & 0 & 25 & 0 & 96 & 49 & 0 & 0 & 0 & 0 & & 0 \\
\hline Peltospira sp & 96 & 48 & 145 & 25 & 120 & 25 & 0 & 0 & 0 & 0 & & 0 \\
\hline Phymorhynchus major & 0 & 0 & 25 & 0 & 0 & 0 & 0 & 0 & 0 & 0 & & 0 \\
\hline Planorbidella planispira ${ }^{\dagger}$ & 0 & 0 & 0 & 25 & 72 & 0 & 0 & 0 & 0 & 0 & 0 & 0 \\
\hline Rhynchopelta concentrica & 25 & 25 & 72 & 0 & 48 & 0 & 0 & 0 & 0 & 0 & 0 & 0 \\
\hline Sutilizona theca $\neq$ & 48 & 169 & 72 & 48 & 386 & 25 & 0 & 0 & 0 & 0 & o & 0 \\
\hline MOLLL & & & & & & & & & & & & \\
\hline Bath & 0 & 0 & 0 & 0 & 0 & 0 & 0 & 0 & 0 & 0 & 0 & 0 \\
\hline Bathypecten vulcani & 0 & 25 & 0 & 0 & 0 & 0 & 0 & 0 & 0 & 0 & b & 0 \\
\hline POLYC & & & & & & & & & & & & \\
\hline Archinome rosacea & 0 & 25 & 120 & 0 & 120 & 0 & 0 & 0 & 0 & 0 & 0 & 0 \\
\hline Nereis sp. & 0 & 0 & 48 & 25 & 72 & 0 & 0 & 0 & 0 & 0 & b & 0 \\
\hline Ophryotrocha akessoni & 265 & 217 & 482 & 96 & 482 & 74 & 0 & 0 & 0 & 0 & o & 0 \\
\hline sphaerids & 193 & 120 & 241 & 120 & 458 & 124 & 0 & 0 & 31 & 0 & b & 0 \\
\hline glycerid & 25 & 0 & 0 & 25 & 25 & 0 & 0 & 0 & 0 & 0 & 0 & 0 \\
\hline nectochaete larvae & 578 & 217 & 193 & 241 & 145 & 124 & 0 & 0 & 31 & 0 & b & 0 \\
\hline hesionid & 0 & 0 & 120 & 25 & 96 & 25 & 0 & 0 & 0 & 0 & 0 & 0 \\
\hline polynoid & 0 & 0 & 145 & 217 & 96 & 99 & 0 & 0 & 0 & 0 & 0 & 0 \\
\hline spionid & 25 & 0 & 48 & 72 & 241 & 25 & 0 & 0 & 0 & 0 & 0 & 0 \\
\hline CRUSTACEA & & & & & & & & & & & & \\
\hline Bythograea $m$ & 0 & 25 & 0 & 0 & 0 & 0 & 0 & 0 & 0 & 0 & 0 & 0 \\
\hline Bythograea thermydron & 25 & 0 & 0 & 0 & 0 & 0 & 0 & 0 & 0 & 0 & 0 & 0 \\
\hline NON- & & & & & & & & & & & & \\
\hline $\mathrm{ampl}$ & 916 & 626 & 2096 & 1108 & 1518 & 1038 & 30 & 30 & 31 & 0 & o & 0 \\
\hline caridean & 25 & 48 & 72 & 72 & 72 & 49 & 0 & 0 & 0 & 51 & 1 & 0 \\
\hline leptostracan (adult) & 48 & 0 & 25 & 96 & 48 & 0 & 0 & 0 & 0 & 0 & b & 0 \\
\hline NON-VENT & & & & & & & & & & & & \\
\hline cyprids (large, non-vent) & 0 & 0 & 0 & 0 & 72 & 0 & 0 & 0 & 31 & 51 & 9 & 96 \\
\hline
\end{tabular}

In prior studies, *unknown gastropod 2; †unknown gastropod W; $¥$ pointy apex 


\begin{tabular}{|c|c|c|c|c|c|c|c|c|c|c|c|c|c|c|c|}
\hline \multicolumn{8}{|c|}{$2007 / 3 \mathrm{mab}$} & \multicolumn{8}{|c|}{$2007 / 75 \mathrm{mab}$} \\
\hline L15 & L16 & L17 & L18 & L19 & L20 & L21 & L22 & L15 & L16 & L17 & L18 & L19 & L20 & L21 & L22 \\
\hline Tica & Tica & Tica & Tica & Tica & Tica & Tica & Tica & Tica & Tica & Tica & Tica & Tica & Tica & Tica & Tica \\
\hline 0 & 1000 & 0 & 1000 & 0 & 1000 & 0 & 1000 & 0 & 1000 & 0 & 1000 & 0 & 1000 & 0 & 1000 \\
\hline 41.5 & 41.5 & 41.5 & 41.5 & 41.5 & 41.5 & 41.5 & 41.5 & 37.1 & 28.8 & 41.5 & 34.2 & 41.5 & 40.6 & 41.5 & 25.2 \\
\hline 24 & 0 & 0 & 0 & 0 & 0 & 0 & 0 & 0 & 0 & 0 & 0 & 0 & 0 & 0 & 0 \\
\hline 0 & 0 & 0 & 0 & 0 & 0 & 0 & 0 & 0 & 0 & 0 & 0 & 0 & 0 & 0 & 0 \\
\hline 0 & 0 & 25 & 0 & 25 & 0 & 0 & 0 & 0 & 0 & 0 & 0 & 0 & 0 & 0 & 0 \\
\hline 145 & 0 & 0 & 0 & 48 & 0 & 120 & 0 & 0 & 0 & 0 & 0 & 0 & 0 & 0 & 0 \\
\hline 25 & 0 & 0 & 25 & 25 & 0 & 0 & 0 & 0 & 0 & 0 & 0 & 0 & 0 & 0 & 0 \\
\hline 602 & 0 & 96 & 0 & 241 & 0 & 385 & 0 & 27 & 0 & 0 & 0 & 0 & 25 & 0 & 40 \\
\hline 0 & 0 & 72 & 0 & 48 & 0 & 25 & 0 & 0 & 0 & 0 & 0 & 0 & 0 & 0 & 0 \\
\hline 0 & 0 & 0 & 0 & 25 & 0 & 0 & 0 & 0 & 0 & 0 & 0 & 0 & 0 & 0 & 0 \\
\hline 0 & 0 & 0 & 0 & 0 & 0 & 0 & 0 & 0 & 0 & 0 & 0 & 0 & 0 & 0 & 0 \\
\hline 96 & 0 & 25 & 0 & 48 & 0 & 72 & 0 & 0 & 0 & 0 & 0 & 0 & 0 & 0 & 0 \\
\hline 6144 & 25 & 1060 & 0 & 4289 & 120 & 4192 & 120 & 54 & 0 & 0 & 0 & 48 & 25 & 25 & 40 \\
\hline 96 & 72 & 72 & 0 & 25 & 72 & 120 & 0 & 243 & 35 & 25 & 0 & 120 & 25 & 48 & 159 \\
\hline 96 & 25 & 0 & 0 & 0 & 0 & 25 & 0 & 0 & 0 & 0 & 0 & 0 & 0 & 0 & 0 \\
\hline 0 & 0 & 0 & 0 & 0 & 0 & 0 & 0 & 0 & 0 & 0 & 0 & 0 & 0 & 0 & 0 \\
\hline 0 & 0 & 0 & 0 & 0 & 0 & 25 & 0 & 0 & 0 & 0 & 0 & 0 & 0 & 0 & 0 \\
\hline 25 & 0 & 0 & 0 & 0 & 0 & 0 & 0 & 0 & 0 & 0 & 0 & 0 & 0 & 0 & 0 \\
\hline 0 & 0 & 0 & 0 & 0 & 0 & 0 & 0 & 0 & 0 & 0 & 0 & 0 & 0 & 0 & 0 \\
\hline 25 & 0 & 0 & 0 & 25 & 0 & 72 & 0 & 0 & 0 & 0 & 0 & 0 & 0 & 0 & 0 \\
\hline 289 & 0 & 25 & 0 & 48 & 0 & 120 & 0 & 0 & 0 & 0 & 0 & 0 & 0 & 0 & 0 \\
\hline 0 & 0 & 0 & 0 & 0 & 0 & 0 & 0 & 0 & 0 & 0 & 0 & 0 & 0 & 0 & 0 \\
\hline 72 & 0 & 0 & 0 & 0 & 0 & 0 & 0 & 0 & 0 & 0 & 0 & 0 & 0 & 0 & 0 \\
\hline 0 & 0 & 0 & 0 & 0 & 0 & 0 & 0 & 0 & 0 & 0 & 0 & 0 & 0 & 0 & 0 \\
\hline 120 & 0 & 48 & 0 & 72 & 25 & 48 & 0 & 0 & 0 & 0 & 0 & 0 & 0 & 0 & 0 \\
\hline 0 & 0 & 0 & 0 & 0 & 0 & 25 & 0 & 0 & 0 & 0 & 0 & 0 & 0 & 0 & 0 \\
\hline 0 & 0 & 0 & 0 & 0 & 0 & 0 & 0 & 0 & 0 & 0 & 0 & 0 & 0 & 0 & 0 \\
\hline 48 & 0 & 0 & 0 & 25 & 0 & 0 & 0 & 0 & 0 & 0 & 0 & 0 & 0 & 0 & 0 \\
\hline 0 & 0 & 0 & 0 & 25 & 0 & 0 & 0 & 0 & 0 & 0 & 0 & 0 & 0 & 0 & 0 \\
\hline 145 & 72 & 96 & 0 & 145 & 25 & 145 & 0 & 27 & 70 & 0 & 0 & 0 & 0 & 0 & 0 \\
\hline 313 & 169 & 313 & 0 & 651 & 0 & 289 & 0 & 0 & 0 & 0 & 0 & 0 & 0 & 0 & 0 \\
\hline 72 & 25 & 25 & 0 & 0 & 0 & 0 & 0 & 0 & 0 & 0 & 0 & 0 & 0 & 0 & 0 \\
\hline 337 & 506 & 169 & 120 & 217 & 25 & 72 & 0 & 0 & 0 & 0 & 0 & 0 & 0 & 0 & 0 \\
\hline 0 & 25 & 25 & 0 & 25 & 0 & 0 & 0 & 0 & 0 & 0 & 0 & 0 & 0 & 0 & 0 \\
\hline 48 & 0 & 48 & 0 & 72 & 0 & 25 & 0 & 0 & 0 & 0 & 0 & 0 & 0 & 0 & 0 \\
\hline 96 & 25 & 25 & 0 & 25 & 0 & 0 & 0 & 0 & 0 & 0 & 0 & 0 & 0 & 0 & 0 \\
\hline 0 & 0 & 0 & 0 & 0 & 0 & 0 & 0 & 0 & 0 & 0 & 0 & 0 & 0 & 0 & 0 \\
\hline 0 & 0 & 0 & 0 & 0 & 0 & 0 & 0 & 0 & 0 & 0 & 0 & 0 & 0 & 0 & 0 \\
\hline 3759 & 289 & 1831 & 0 & 2747 & 25 & 3036 & 0 & 0 & 0 & 0 & 0 & 0 & 0 & 0 & 79 \\
\hline 0 & 0 & 25 & 0 & 0 & 0 & 0 & 25 & 0 & 0 & 0 & 0 & 0 & 0 & 0 & 0 \\
\hline 72 & 0 & 25 & 0 & 2963 & 0 & 1614 & 0 & 0 & 0 & 0 & 0 & 0 & 0 & 0 & 0 \\
\hline 0 & 0 & 48 & 0 & 0 & 0 & 0 & 0 & 54 & 139 & 0 & 29 & 145 & 49 & 96 & 40 \\
\hline
\end{tabular}


Table 3. Variation in larval abundance in two-way analysis of variance with Vertical ( 3 and $75 \mathrm{~m}$ above bottom) and Cross-ridge (on axis and 100 or $1000 \mathrm{~m}$ off axis) positions as fixed factors. Abundances were log transformed $\ln (x+1)$ and separate analyses were conducted for $2006(n=$ 3 ) and $2007(n=4)$. Taxa analyzed were pooled larvae (all vent species), gastropod larvae (all vent gastropod species), polychaete larvae (all vent polychaete species), amphipods (adults of vent species Halice hesmonectes) and cyprids (a non-vent barnacle species). Bold denotes significant differences $(P<0.05)$ with Bonferroni correction for multiple tests.

\begin{tabular}{|c|c|c|c|c|c|c|c|c|c|c|c|c|}
\hline & \multicolumn{6}{|l|}{2006} & \multicolumn{6}{|l|}{2007} \\
\hline & \multicolumn{2}{|l|}{ Vertical } & \multicolumn{2}{|c|}{ Cross-ridge } & \multicolumn{2}{|c|}{ Interact } & \multicolumn{2}{|c|}{ Vertical } & \multicolumn{2}{|c|}{ Cross-ridge } & \multicolumn{2}{|c|}{ Interact } \\
\hline & $\mathrm{F}$ & $P$ & $\mathrm{~F}$ & $P$ & $\mathrm{~F}$ & $P$ & $\mathrm{~F}$ & $P$ & $\mathrm{~F}$ & $P$ & $\mathrm{~F}$ & $P$ \\
\hline Pooled larvae & 48.6 & $<0.001$ & 2.3 & 0.17 & 0.01 & 0.91 & 31.3 & $<0.001$ & 14.6 & 0.002 & 8.91 & 0.011 \\
\hline Gastropod larvae & 35.1 & 0.001 & 1.2 & 0.31 & 0.22 & 0.66 & 22.7 & $<0.001$ & 24.2 & $<0.001$ & 13.15 & 0.003 \\
\hline Polychaete larvae & 168.8 & $<0.001$ & 5.3 & 0.05 & 0.53 & 0.49 & 29.3 & $<0.001$ & 4.4 & 0.057 & 6.05 & 0.030 \\
\hline Amphipod & 170.3 & $<0.001$ & 1.3 & 0.29 & 0.37 & 0.56 & 52.3 & $<0.001$ & 24.9 & $<0.001$ & 35.86 & $<0.001$ \\
\hline Cyprid (non-vent) & 1.4 & 0.272 & 0.1 & 0.72 & 0.54 & 0.49 & 13.9 & 0.003 & 0.2 & 0.652 & 0.26 & 0.620 \\
\hline
\end{tabular}




\section{Figures}
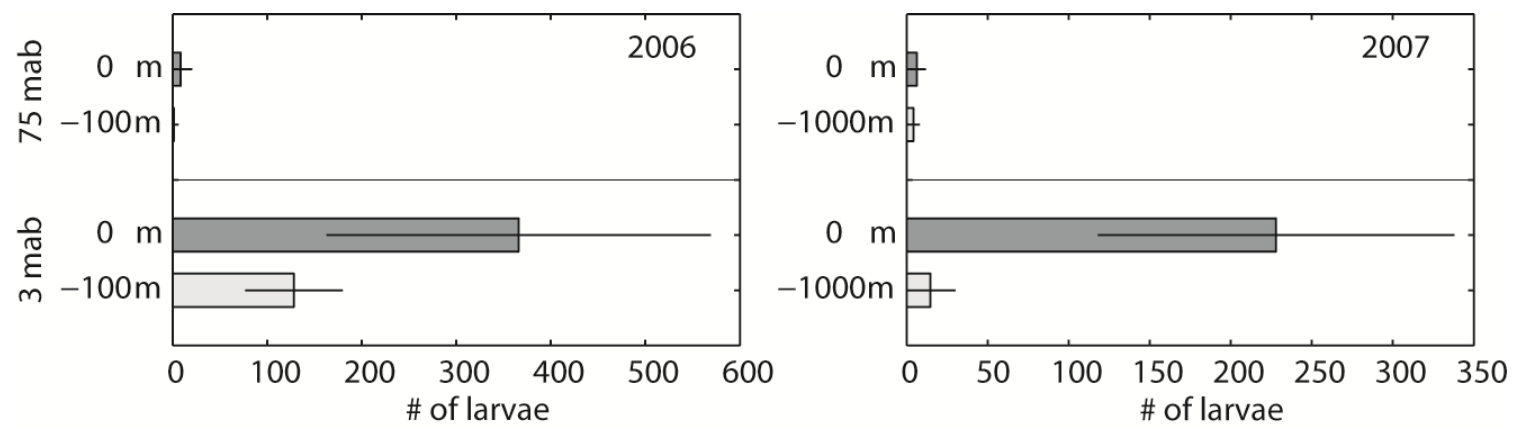

Fig. 1. Abundance of vent larvae (no. larvae per $40,000 \mathrm{~L}$ ), all taxa pooled, in pump samples at heights of $3 \mathrm{~m}$ and $75 \mathrm{~m}$ above bottom, on axis (dark bars) and off axis (light bars). Off-axis samples were positioned $100 \mathrm{~m}$ east of vents $(-100 \mathrm{~m})$ in 2006 and $1000 \mathrm{~m}$ east $(-1000 \mathrm{~m})$ in 2007. Error bars are standard deviation. 

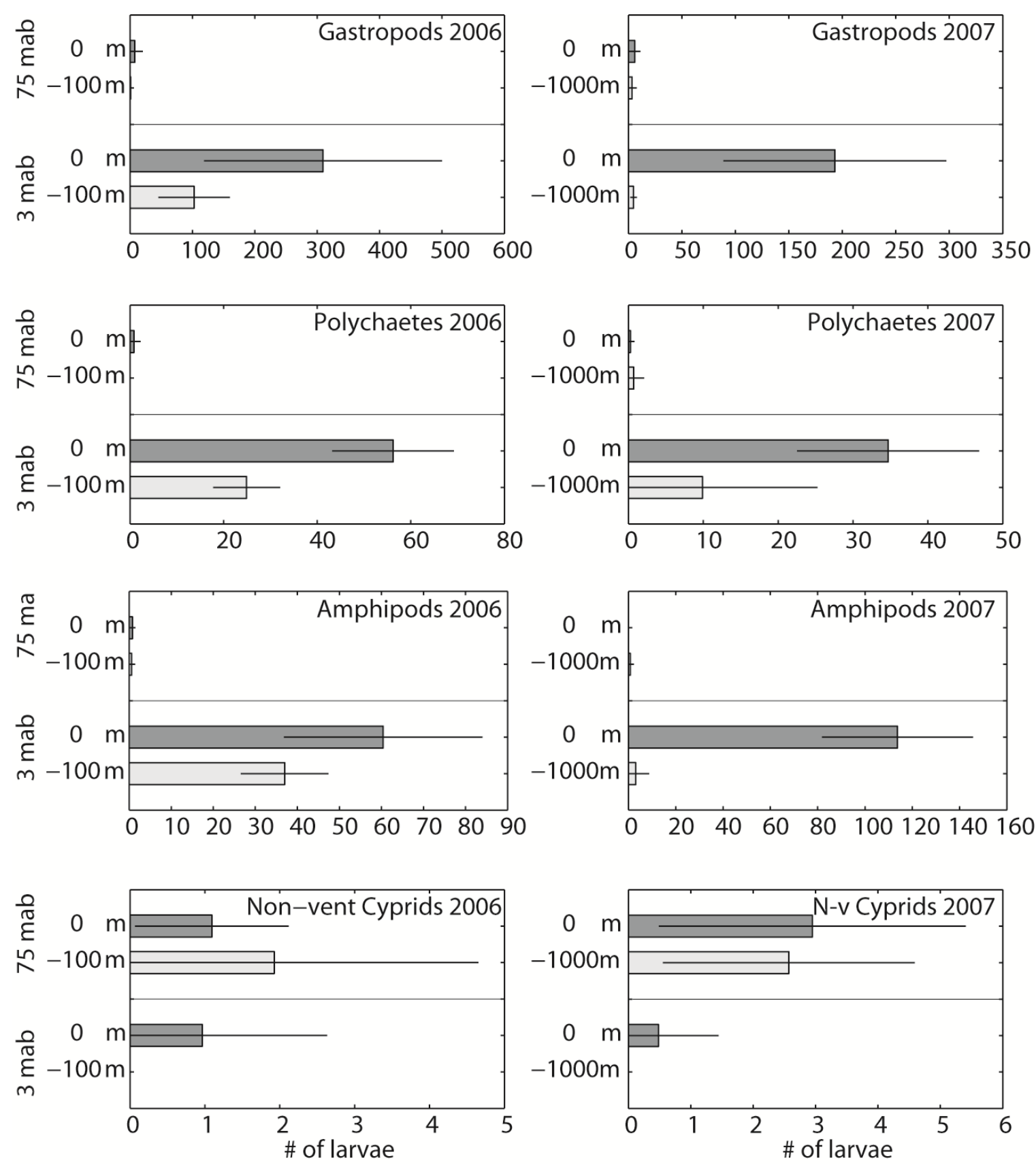

Fig. 2. Abundance (no. larvae per $40,000 \mathrm{~L}$ ) of gastropod larvae (vent taxa pooled), polychaete larvae (vent taxa pooled), adult vent amphipods (Halice hesmonectes) and non-vent cyprids (unknown barnacle species) in pump samples at heights of $3 \mathrm{~m}$ and $75 \mathrm{~m}$ above bottom, on axis (dark bars) and off axis (light bars). Off-axis samples were positioned $100 \mathrm{~m}$ east of vents (-100 $\mathrm{m})$ in 2006 and $1000 \mathrm{~m}$ east $(-1000 \mathrm{~m})$ in 2007 . Error bars are standard deviation. 
Lepetodrilus spp.
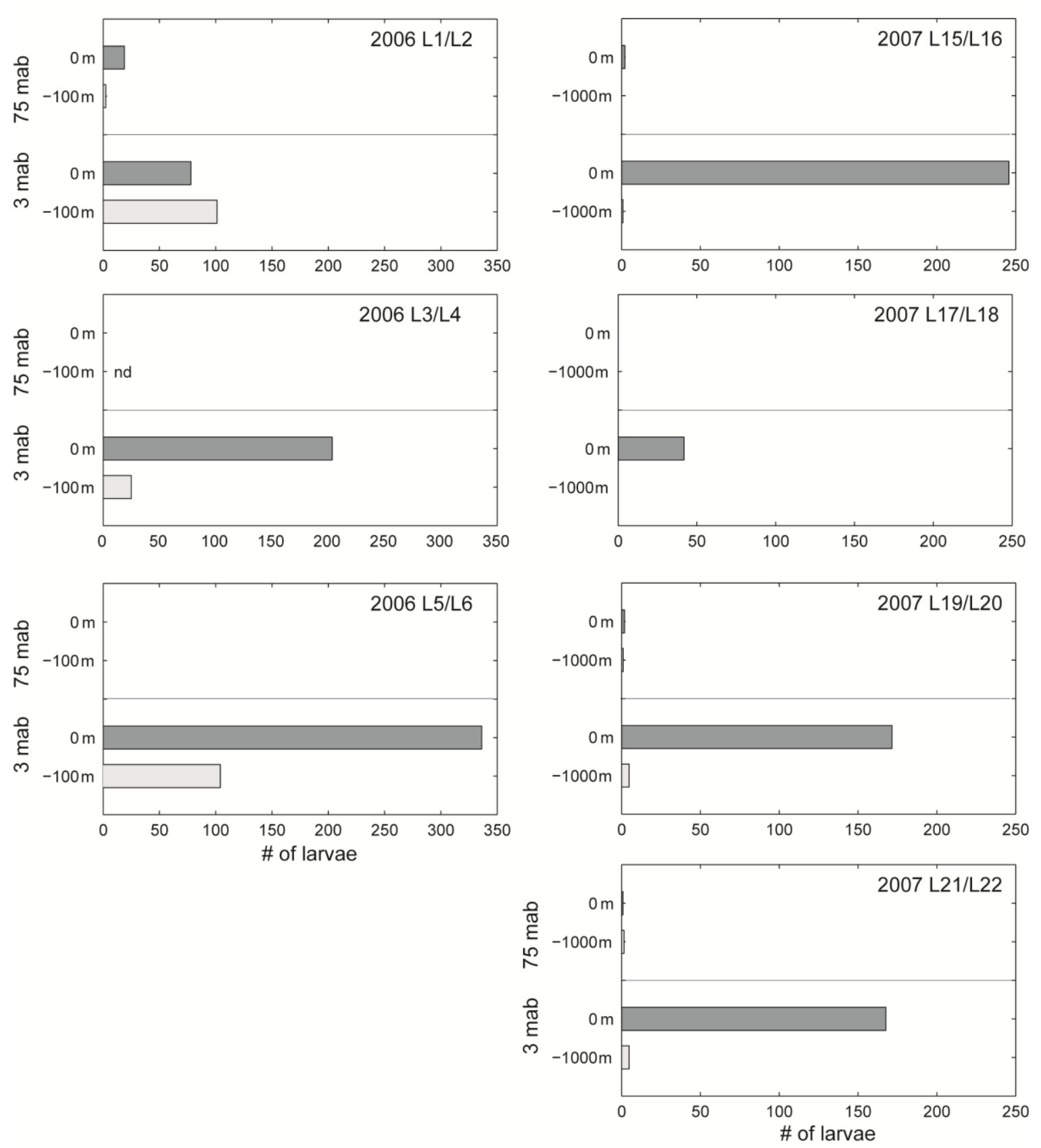

Fig. 3. Day-to-day variation in abundance (no. larvae per $1000 \mathrm{~m}^{3}$ ) of Lepetodrilus spp. (gastropod) larvae in pump samples at heights of $3 \mathrm{~m}$ and $75 \mathrm{~m}$ above bottom, on axis (dark bars) and off axis (light bars). The L4 pump at 75 mab collected no sample (nd). Off-axis samples were positioned $100 \mathrm{~m}$ east of vents $(-100 \mathrm{~m})$ in 2006 and $1000 \mathrm{~m}$ east $(-1000 \mathrm{~m})$ in 2007. Collections were made at three different sites in 2006, but at one site in 2007. Mooring deployment IDs are indicated in the upper right of each panel; see Table 1 for details. 
Ophryotrocha akessoni
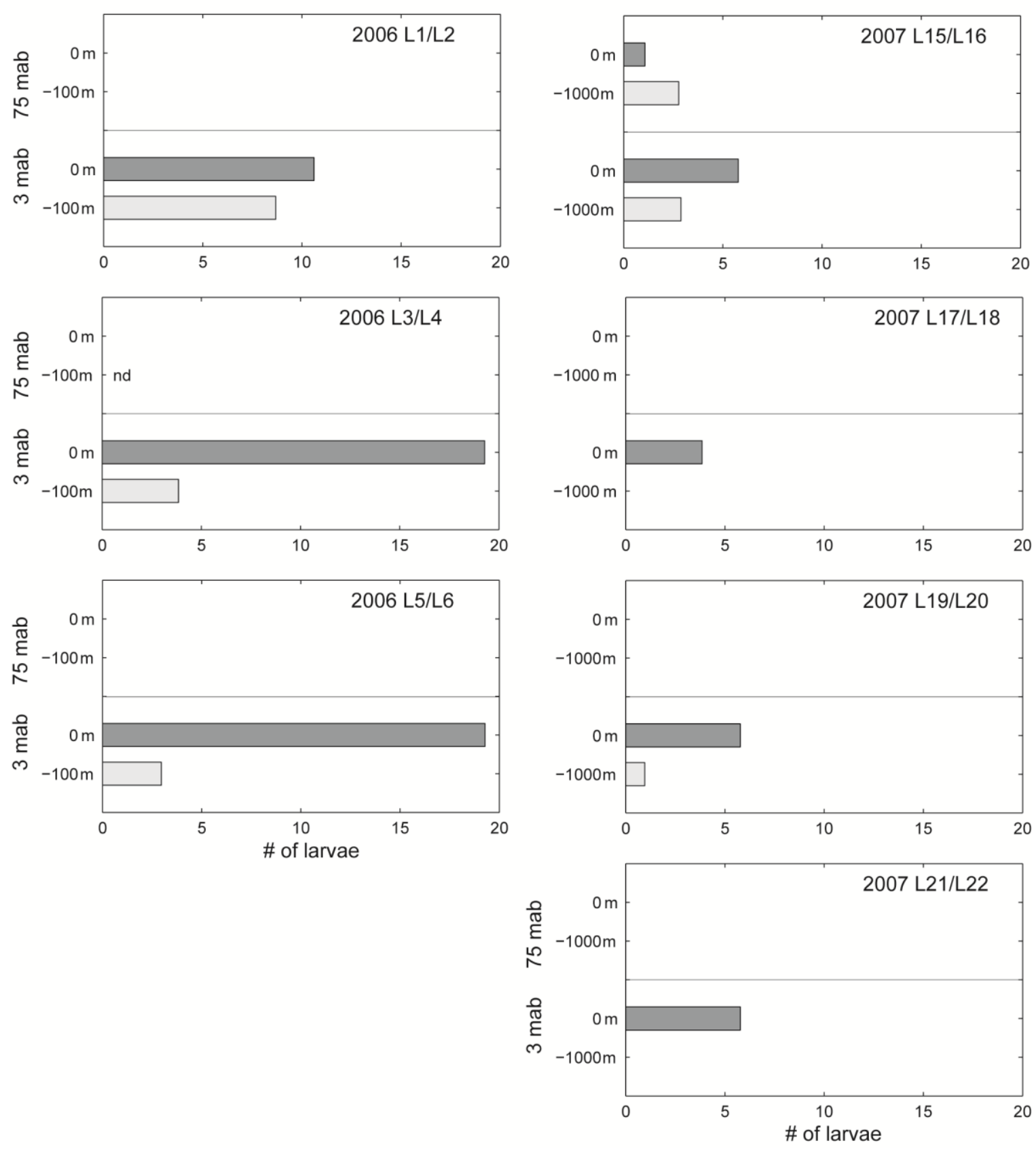

Fig. 4. Day-to-day variation in abundance (no. larvae per 40,000 L) of Ophryotrocha akessoni (polychaete) larvae in pump samples at heights of $3 \mathrm{~m}$ and $75 \mathrm{~m}$ above bottom, on axis (dark bars) and off axis (light bars). The L4 pump at 75 mab collected no sample (nd). Off-axis samples were positioned $100 \mathrm{~m}$ east of vents $(-100 \mathrm{~m})$ in 2006 and $1000 \mathrm{~m}$ east $(-1000 \mathrm{~m})$ in 2007. Collections were made at three different sites in 2006, but at one site in 2007. Mooring deployment IDs are indicated in the upper right of each panel; see Table 1 for details. 

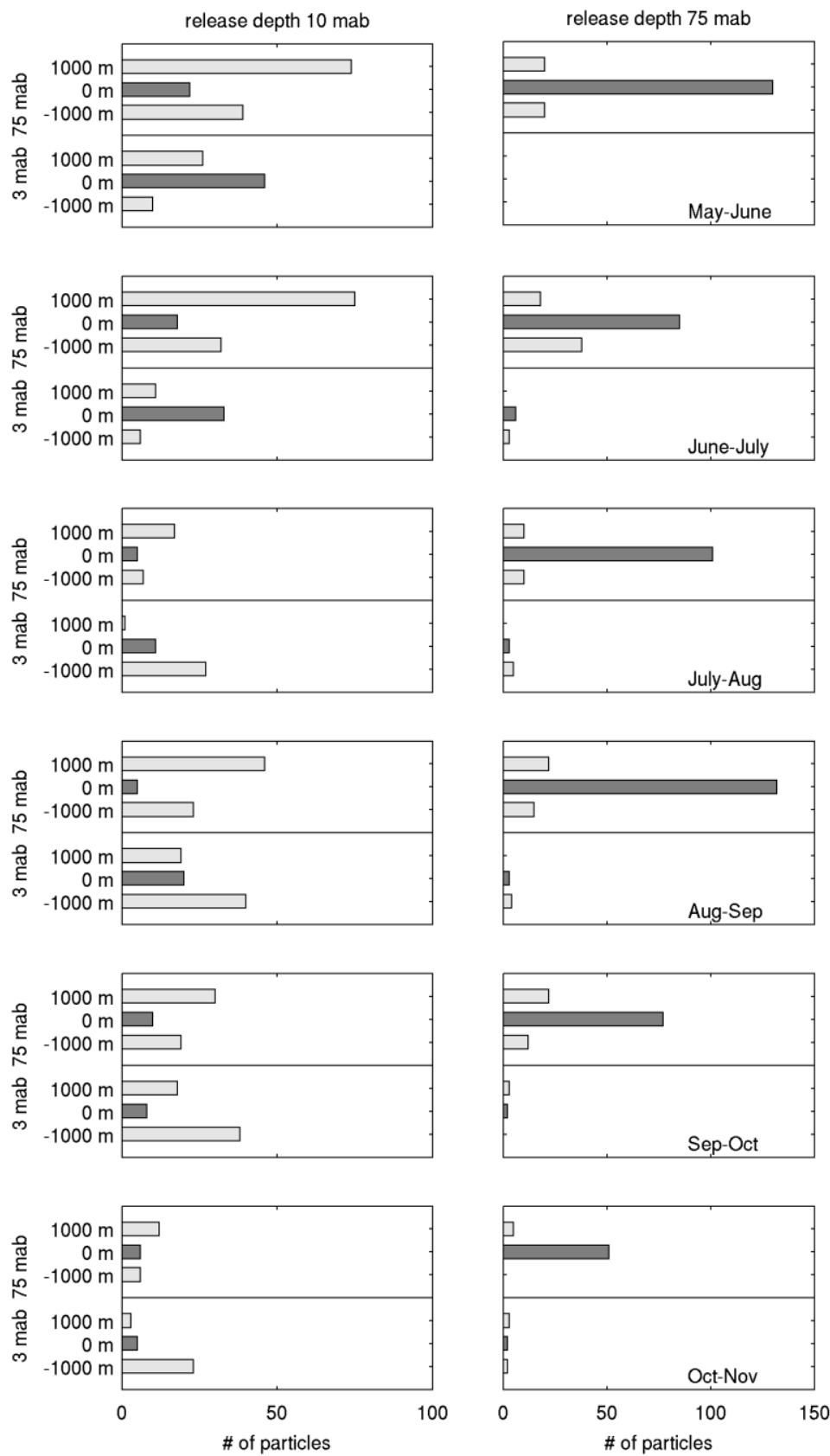

Fig. 5. Time-series of simulated plankton pump captures of passive particles released at $10 \mathrm{mab}$ (left) and 75 mab (right). Near-bottom ( $3 \mathrm{mab}$ ) and off-bottom (75 mab) samplers are located at the ridge axis $(0 \mathrm{~m})$ and on the eastern $(1000 \mathrm{~m})$ and western $(-1000 \mathrm{~m})$ flanks. 

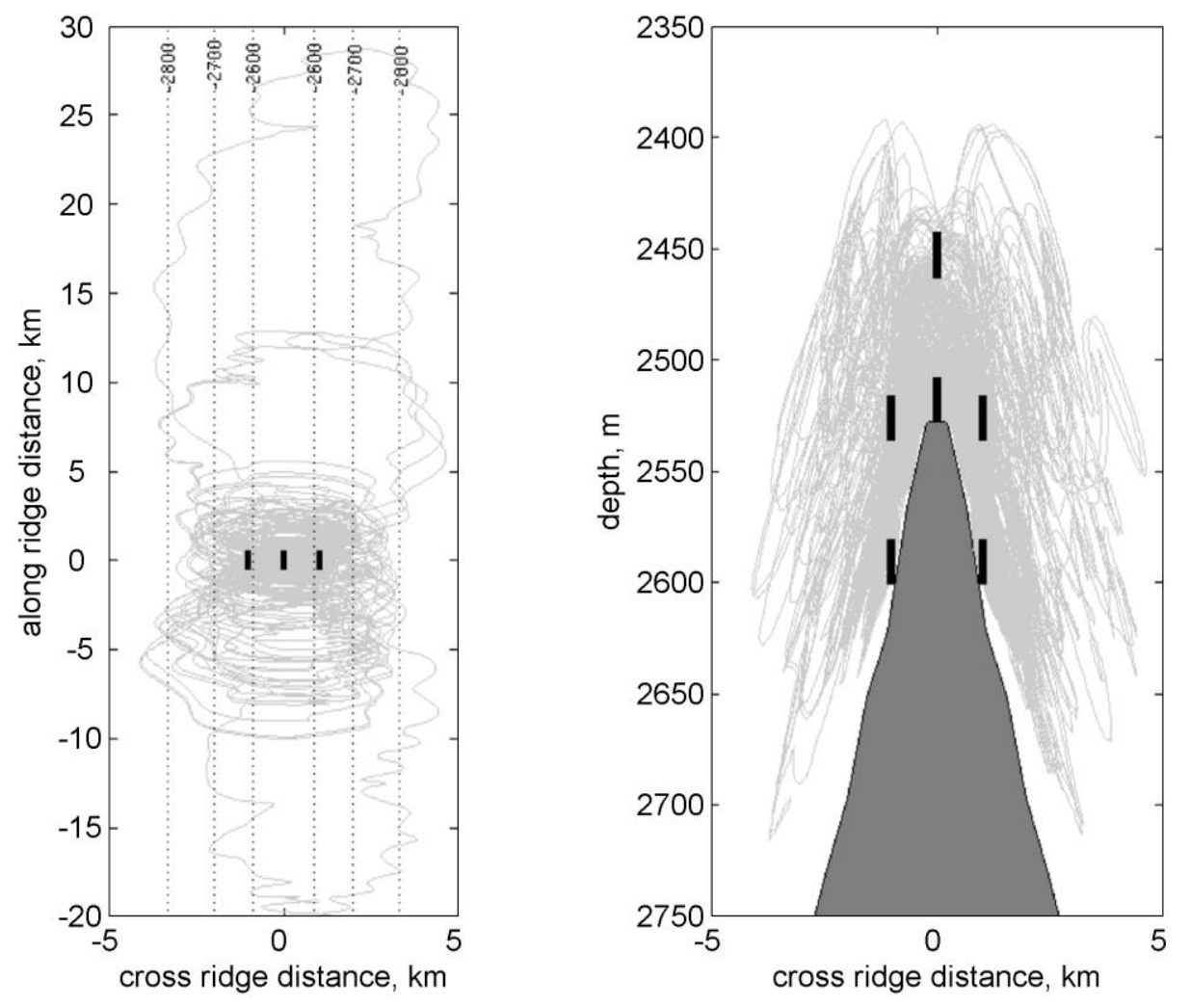

Fig. 6. Trajectories of particles released at 10 mab that were subsequently captured by the simulated plankton pumps for the May-June period. Left panel: plan view. Right panel: vertical section. Locations of the simulated plankton pumps indicated by black rectangles. Particle tracks indicated by light gray lines. Bathymetric contours are shown as dotted lines in the left panel. 


\section{Active Positioning of Vent Larvae at a Mid-Ocean Ridge}

Mullineaux, L.S. ${ }^{a *}$, D.J. McGillicuddy Jr. ${ }^{b}$, S.W. Mills ${ }^{a}$, V. K. Kosnyrev ${ }^{b}$, A.M. Thurnherr ${ }^{c}$, J.R. Ledwell $^{\mathrm{b}}$, J.W. Lavelle ${ }^{\mathrm{d}}$

a Biology Department, Woods Hole Oceanographic Institution Woods Hole, MA 02543, United States

${ }^{\mathrm{b}}$ Department of Applied Ocean Engineering and Physics, Woods Hole Oceanographic Institution, Woods Hole, MA 02543, United States

' Division of Ocean and Climate Physics, Lamont-Doherty Earth Observatory, Palisades, NY 10964-8000, United States

d NOAA/Pacific Marine Environmental Laboratory, Seattle, WA 98115, United States

*Corresponding author: Imullineaux@whoi.edu, phone 508 289-2898; fax 508 457-2134

Supplementary Information

(Table S1, Figs. S1-S6) 
Supplementary Table S1. Abundance (no. per $1000 \mathrm{~m}^{3}$ ) of all larvae and juveniles in pump samples in 2006 (on and $100 \mathrm{~m}$ off axis) and 2007 (on and $1000 \mathrm{~m}$ off axis) at 3 and $75 \mathrm{~m}$ above bottom (mab). Pumps were located at Riftia Field, Tica and Ty/lo vents.

\begin{tabular}{|c|c|c|c|c|c|c|c|c|c|c|c|c|c|c|c|c|c|c|c|c|c|c|c|c|c|c|c|c|}
\hline Date/Height & $2006 /$ & $3 \mathrm{mab}$ & & & & & $2006 / 7$ & $75 \mathrm{mab}$ & & & & $2007 /$ & $3 \mathrm{mab}$ & & & & & & & $2007 / 7$ & $75 \mathrm{mak}$ & & & & & & & \\
\hline Mooring Number & L1 & $\mathrm{L} 2$ & $\overline{L 3}$ & $\overline{L 4}$ & $\overline{L 5}$ & $\overline{\mathrm{L} 6}$ & L1 & L2 & $\overline{L 3}$ & $\mathrm{L5}$ & $\overline{\mathrm{L} 6}$ & L15 & L16 & L17 & L18 & L19 & $\overline{L 20}$ & L21 & $\overline{\mathrm{L} 22}$ & $\mathrm{L15}$ & L16 & $\mathrm{L}_{\mathrm{L} 17}$ & L18 & L19 & & 20 & $\mathrm{~L} 21$ & L22 \\
\hline Location & Ty/lo & Ty/lo & Tica & Tica & Riftia & Riftia & Ty/lo T & $\mathrm{Ty} / \mathrm{lo}$ & Tica & Riftia & Riftia & Tica & Tica & Tica & Tica & Tica & Tica 1 & Tica & Tica & Tica & Tica & Tica & Tica & Tica & Tic & ca & Tica & Tica \\
\hline Distance off axis $(\mathrm{m})$ & 0 & 100 & 0 & 100 & 0 & 100 & 0 & 100 & 0 & 0 & 100 & 0 & 1000 & 0 & 1000 & 0 & 1000 & 0 & 1000 & 0 & 1000 & 0 & 1000 & 0 & & 000 & 0 & 1000 \\
\hline Volume $\left(\mathrm{m}^{-3}\right)$ & 41.5 & 41.5 & 41.5 & 41.5 & 41.5 & 40.4 & 33.6 & 33.7 & 32.1 & 39.3 & 41.5 & 41.5 & 41.5 & 41.5 & 41.5 & 41.51 & 41.51 & 41.5 & 41.5 & 37.1 & 28.8 & 41.5 & 34.2 & 41.5 & & 0.6 & 41.5 & 25.2 \\
\hline MOLLUSCA - GASTROPODA & & & & & & & & & & & & & & & & & & & & & & & & & & & & \\
\hline Bathymargari & 0 & 0 & 0 & 0 & 0 & 0 & 0 & 0 & 0 & 0 & 0 & 24 & 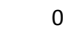 & 0 & 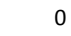 & 0 & 0 & & & 0 & & & & & 0 & 0 & & \\
\hline Clypeosectus delectus & 0 & 0 & 48 & 0 & 48 & 49 & 0 & 0 & 0 & 0 & 0 & 0 & 0 & 0 & 0 & 0 & 0 & 0 & 0 & 0 & 0 & & 0 & 0 & 0 & 0 & 0 & \\
\hline Ctenop & 25 & 25 & 72 & 0 & 169 & 49 & 0 & 0 & 0 & 0 & 0 & 0 & 0 & 25 & 0 & 25 & 0 & 0 & 0 & 0 & 0 & & 0 & 0 & 0 & 0 & 0 & \\
\hline Cyathe & 96 & 72 & 25 & 0 & 169 & 0 & 0 & 0 & 0 & 0 & 0 & 145 & 0 & 0 & 0 & 48 & 0 & 120 & 0 & 0 & 0 & & 0 & 0 & 0 & 0 & 0 & \\
\hline Echin & 25 & 0 & 0 & 0 & 145 & 25 & 30 & 0 & 0 & 0 & 0 & 25 & 0 & 0 & 25 & 25 & 0 & 0 & 0 & 0 & 0 & & 0 & b & . & 0 & 0 & \\
\hline Gorgol & 795 & 554 & 1036 & 120 & 2144 & 25 & 59 & 0 & 0 & 0 & 0 & 602 & 0 & 96 & 0 & 241 & 0 & 385 & 0 & 27 & 0 & & 0 & 0 & 0 & 25 & 0 & 40 \\
\hline Gorgo & 0 & 0 & 48 & 0 & 25 & 74 & 0 & 0 & 0 & 0 & O & 0 & 0 & 0 & 0 & 25 & 0 & 0 & 0 & 0 & 0 & & 0 & & 0 & 0 & 0 & \\
\hline$E u$ & 0 & 0 & 25 & 0 & 25 & 0 & 0 & 0 & 0 & 0 & 0 & 0 & 0 & 0 & 0 & 0 & 0 & 0 & 0 & 0 & 0 & & 0 & & 0 & 0 & 0 & \\
\hline Lae & 120 & 72 & 120 & 25 & 506 & 198 & 0 & 0 & 0 & 0 & 0 & 96 & 0 & 25 & 0 & 48 & 0 & 72 & 0 & 0 & & & 0 & & 0 & 0 & 0 & \\
\hline Lep & 1952 & 2530 & 5083 & 626 & 8409 & 2571 & 476 & 59 & 0 & 0 & 0 & 6144 & 25 & 1060 & 0 & 4289 & 120 & 4192 & 120 & 54 & 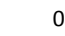 & & 0 & b & 48 & 25 & 25 & \\
\hline Lepe & 0 & 0 & 25 & 0 & 0 & 0 & 0 & 0 & 0 & 0 & 0 & 96 & 72 & 72 & 0 & 49 & 72 & 120 & 0 & 243 & 35 & 25 & 5 & $\begin{array}{ll}0 & 12\end{array}$ & 20 & 25 & 48 & 159 \\
\hline Lepe & 0 & 0 & 24 & 0 & 0 & 0 & 0 & 0 & 0 & 0 & 0 & 24 & 0 & 24 & 0 & 0 & 0 & 0 & 0 & 0 & 0 & & 0 & 0 & 0 & 0 & 0 & \\
\hline Lir & 0 & 0 & 48 & 25 & 48 & 49 & 0 & 0 & 0 & 0 & 0 & 96 & 25 & 0 & c & 0 & 0 & 25 & 0 & c & 0 & & 0 & & 0 & 0 & & \\
\hline Melan & 48 & 0 & 48 & 25 & 72 & 25 & 0 & 0 & 0 & 0 & 0 & 0 & O & 0 & 0 & 0 & 0 & 0 & & 0 & 0 & & 0 & & 0 & 0 & 0 & \\
\hline$M$ & 0 & 0 & 0 & 0 & 0 & 0 & 0 & 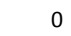 & 0 & 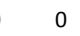 & 0 & 0 & 0 & 0 & 0 & 0 & 0 & 25 & . & 0 & . & & 0 & 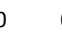 & 0 & 0 & 0 & \\
\hline Melo & 0 & 0 & 0 & 0 & 48 & 0 & 0 & 0 & 0 & 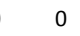 & 0 & 0 & 0 & 0 & 0 & 0 & 0 & 0 & & 0 & 0 & & 0 & & 0 & 0 & 0 & \\
\hline $\mathrm{Nec}$ & 0 & 0 & 72 & 0 & 72 & 0 & 0 & 0 & 0 & 0 & 0 & 25 & 0 & 0 & 0 & 0 & 0 & 0 & 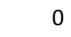 & 0 & 0 & & 0 & b & 0 & 0 & 0 & \\
\hline $\mathrm{NeOl}$ & 0 & 0 & 0 & 0 & 0 & 25 & 0 & 0 & 0 & 0 & 0 & 0 & . & 0 & 0 & 0 & 0 & 0 & & 0 & 0 & & 0 & & 0 & 0 & 0 & \\
\hline Pelt & 96 & 48 & 145 & 25 & 120 & 25 & 0 & 0 & 0 & 0 & 0 & 289 & 0 & 25 & c & 48 & 0 & 120 & & & 0 & & 0 & & 0 & 0 & 0 & \\
\hline Phy & 0 & 0 & 25 & 0 & 0 & 0 & 0 & 0 & 0 & 0 & 0 & 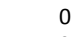 & 0 & 0 & 0 & 0 & 0 & 0 & & & & & 0 & & & 0 & 0 & \\
\hline & 0 & 0 & 0 & 25 & 72 & 0 & 0 & 0 & 0 & 0 & 0 & 72 & 0 & 0 & c & & 0 & 0 & 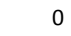 & 0 & 0 & & 0 & & 0 & 0 & 0 & \\
\hline Rhyn & 25 & 25 & 72 & 0 & 48 & O & 0 & 0 & 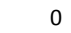 & 0 & 0 & 0 & 0 & 0 & 0 & 0 & 0 & 0 & & 0 & c & & 0 & & & 0 & 0 & \\
\hline Sut & $4 \varepsilon$ & 16 & 7 & 48 & 386 & 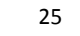 & 0 & 0 & & & 0 & 120 & 0 & 48 & c & 7 & 25 & 48 & & & 0 & & 0 & & 0 & 0 & 0 & \\
\hline & 7 & 24 & 72 & 2 & 193 & ? & 0 & 0 & 0 & 0 & 0 & 96 & 0 & 0 & 0 & 24 & 0 & 0 & & & 0 & & 0 & & & 0 & 0 & \\
\hline & 96 & 217 & 289 & 72 & 651 & 124 & & 0 & 0 & & 0 & 193 & 0 & 72 & 0 & 169 & 0 & 120 & & 27 & & & 0 & & 0 & 0 & 0 & \\
\hline & 0 & 0 & 0 & 0 & 0 & 0 & 0 & 0 & 0 & 0 & 0 & 0 & 0 & 0 & 0 & 0 & 0 & 0 & & 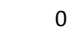 & c & & 0 & & 0 & 25 & 0 & \\
\hline $0-175 \mu \mathrm{m}$ & 0 & 24 & 0 & 0 & 0 & 0 & 0 & 0 & 0 & 0 & 0 & c & 0 & 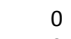 & 0 & 0 & 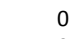 & 0 & & c & & & 0 & & 0 & 0 & 0 & \\
\hline Un & 0 & O & 0 & 0 & 24 & 0 & & 0 & 0 & 0 & 0 & & 0 & 0 & & & 0 & & & & 0 & & 0 & & 0 & 0 & . & \\
\hline & 0 & 0 & 0 & 0 & 0 & 0 & 0 & 0 & 0 & 0 & 0 & 0 & 0 & 0 & 0 & 24 & 0 & u & 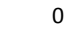 & U & c & & 0 & & & 0 & 0 & \\
\hline & 0 & 0 & 0 & 0 & . & 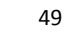 & 0 & 0 & & 20 & 0 & 48 & 0 & 0 & & & 0 & 24 & & 81 & & & 0 & & 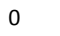 & 0 & 0 & \\
\hline & 0 & 0 & 0 & 0 & 0 & 2 & 0 & 0 & 0 & 0 & & 0 & 0 & 0 & & & 0 & 0 & & 0 & c & & 0 & & & 0 & 0 & \\
\hline & 48 & 24 & 24 & 24 & 169 & 74 & 0 & 0 & 0 & 0 & 0 & 2 & 0 & 0 & ( & 2 & 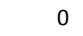 & & & & 0 & & 0 & 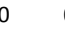 & 0 & 0 & 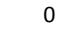 & \\
\hline un & 0 & 0 & 0 & 0 & 0 & 0 & 0 & 0 & 0 & 0 & 0 & 48 & 24 & 24 & 0 & 48 & 0 & & & & c & & 0 & 0 & 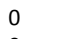 & 0 & 0 & 40 \\
\hline & 0 & 2 & 2 & . & 313 & 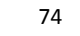 & 0 & 0 & & 0 & 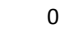 & 15 & 0 & 0 & & 2 & . & & & & & & 0 & & & 0 & & \\
\hline possit & 0 & 72 & 120 & 0 & 24 & 49 & 0 & 59 & 93 & 432 & 0 & 145 & 0 & 169 & 24 & 24 & 48 & 24 & 0 & 0 & 0 & & $5 s$ & & 0 & 25 & 241 & $15 c$ \\
\hline & & & & & & & & & & & & & & & & & & & & & & & & & & & & \\
\hline oph & 0 & 0 & 0 & 0 & 0 & 0 & 0 & 0 & 0 & 0 & 0 & 0 & 0 & 0 & 0 & & 0 & 25 & & 0 & 0 & c & 0 & 0 & 0 & 0 & 0 & \\
\hline $\mathrm{Te}$ & 0 & 0 & 0 & 0 & 0 & 0 & 0 & 0 & 0 & 0 & 0 & 0 & 0 & 0 & 0 & 24 & 0 & 0 & & 0 & 0 & 24 & & 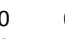 & 0 & 0 & 0 & \\
\hline & 0 & 25 & 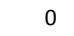 & U & 0 & 0 & 0 & 0 & . & 0 & & c & 0 & 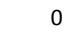 & & & 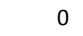 & & & & & c & 0 & & & 0 & 0 & \\
\hline other possible bivalve, inc D-stage & 0 & 24 & 0 & 24 & 0 & 25 & 0 & 0 & 0 & 0 & 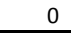 & 72 & 48 & 24 & 24 & 0 & 0 & 0 & 0 & 0 & 0 & & 0 & 0 & 0 & 0 & 0 & \\
\hline
\end{tabular}

In prior studies, *unknown gastropod 2; tunknown gastropod W; ¥ pointy apex 


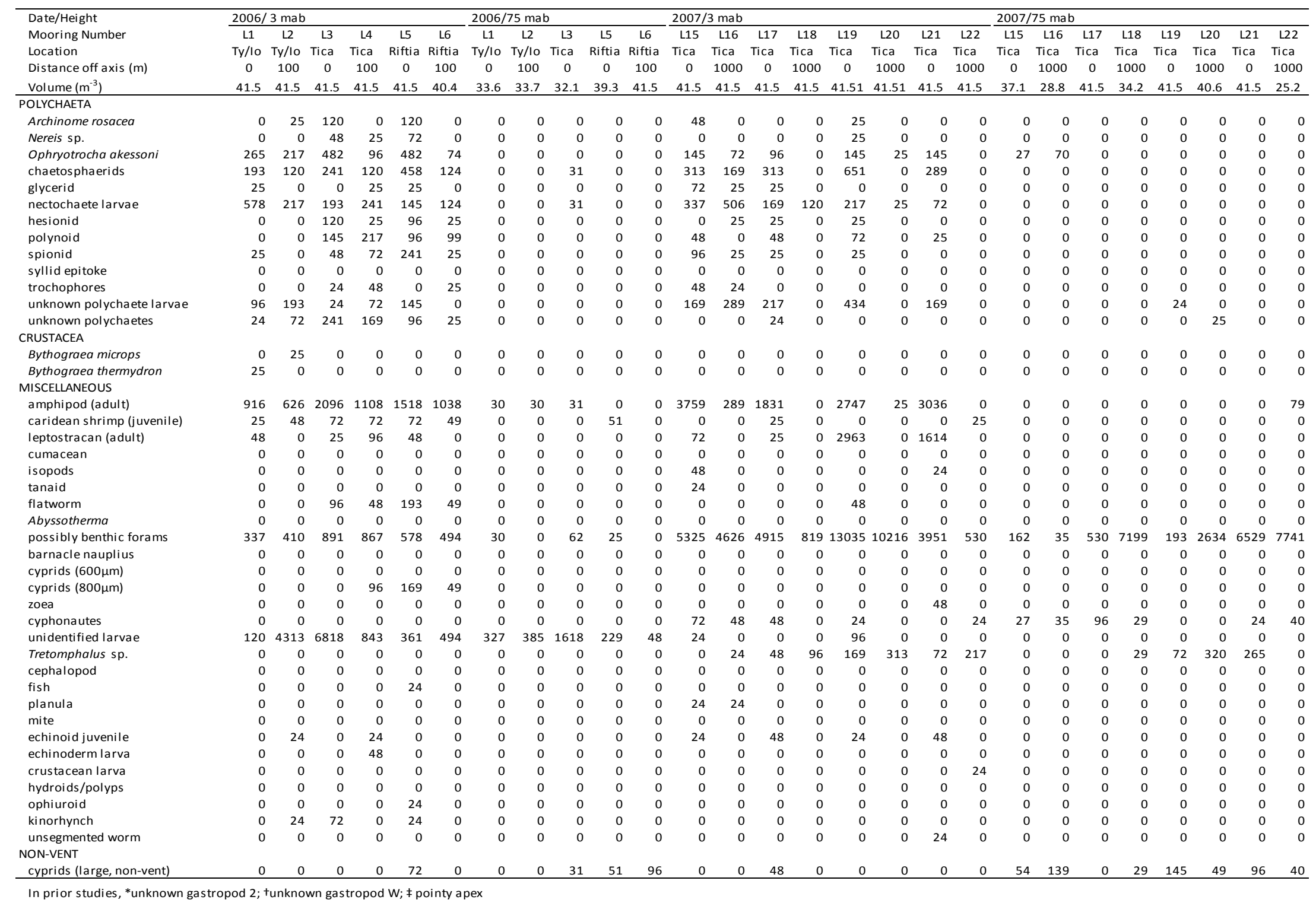


Gorgoleptis emarginatus
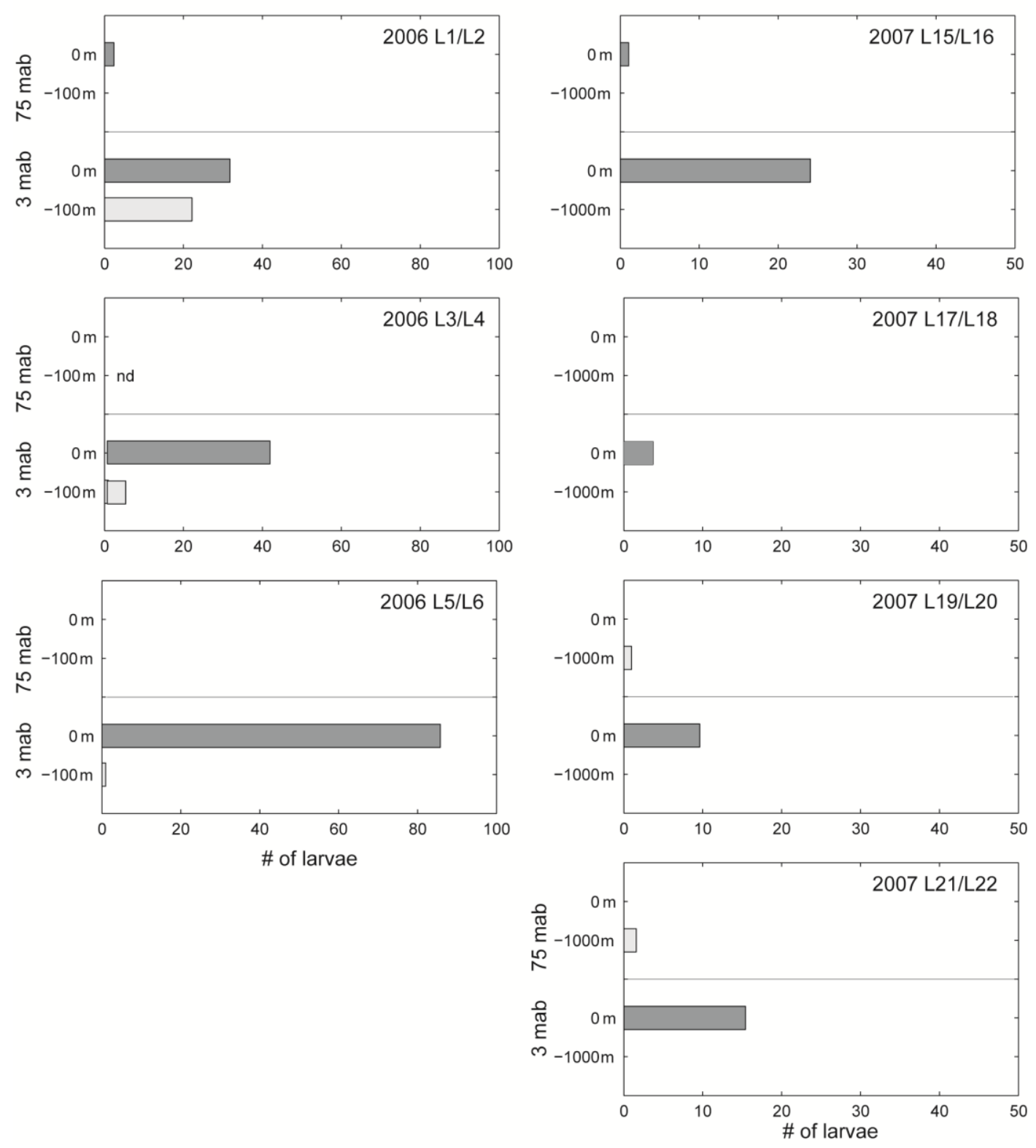

Supplementary Fig. S1. Day-to-day variation in abundance (no. larvae per 40,000 L) of Gorgoleptis emarginatus (gastropod) larvae in pump samples at heights of $3 \mathrm{~m}$ and $75 \mathrm{~m}$ above bottom, on axis (dark bars) and off axis (light bars). The L4 pump at 75 mab collected no sample (nd). Off-axis samples were positioned $100 \mathrm{~m}$ east of vents $(-100 \mathrm{~m})$ in 2006 and $1000 \mathrm{~m}$ east $(-1000 \mathrm{~m})$ in 2007 . Collections were made at three different sites in 2006, but at one site in 2007. Mooring deployment IDs are indicated in the upper right of each panel; see Table 1 for details. 
Peltospira sp.
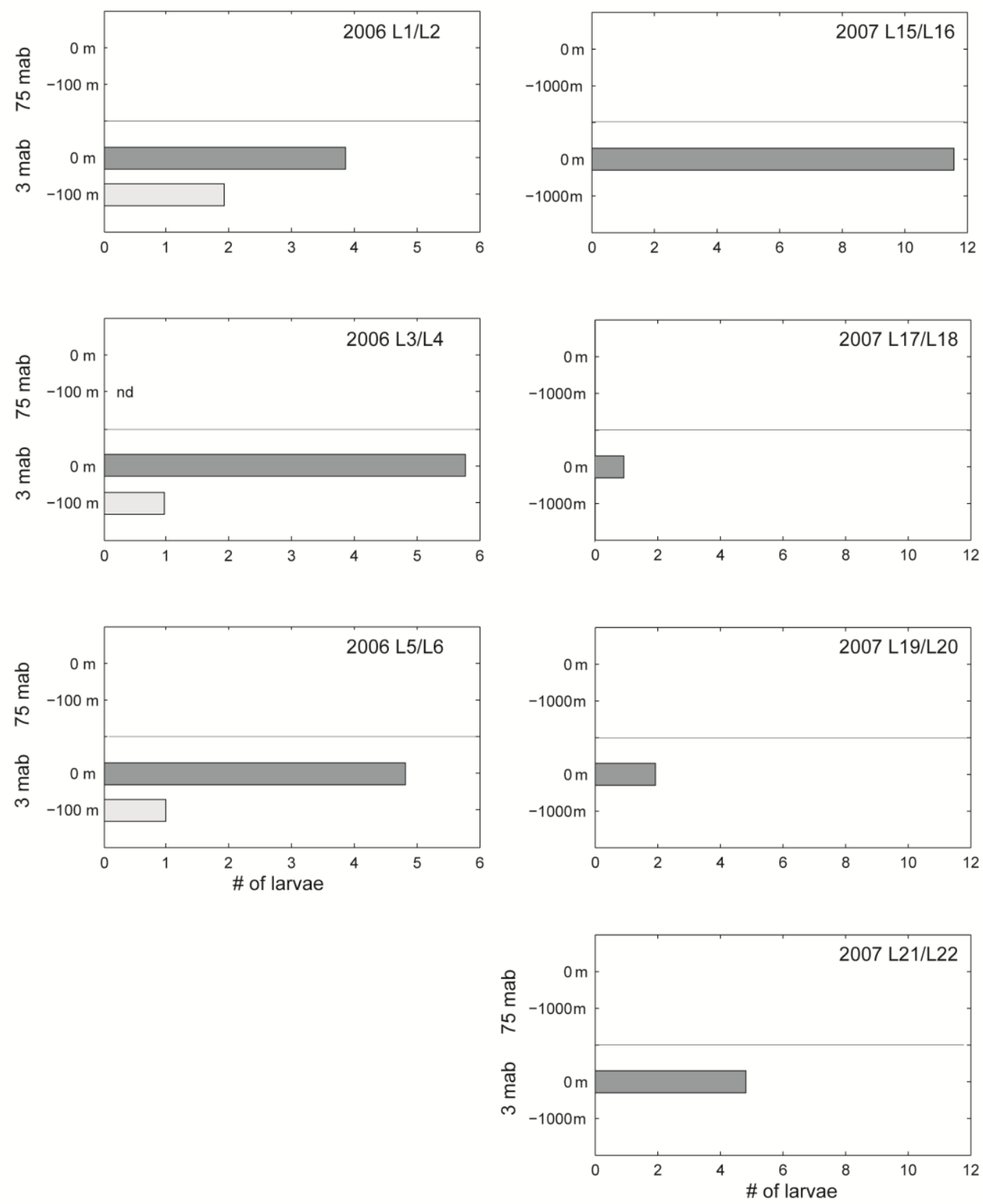

Supplementary Fig. S2. Day-to-day variation in abundance (no. larvae per 40,000 L) of Peltospira sp. (gastropod) larvae in pump samples at heights of $3 \mathrm{~m}$ and $75 \mathrm{~m}$ above bottom, on axis (dark bars) and off axis (light bars). Details as in Fig. S1. 
Sutilizona theca
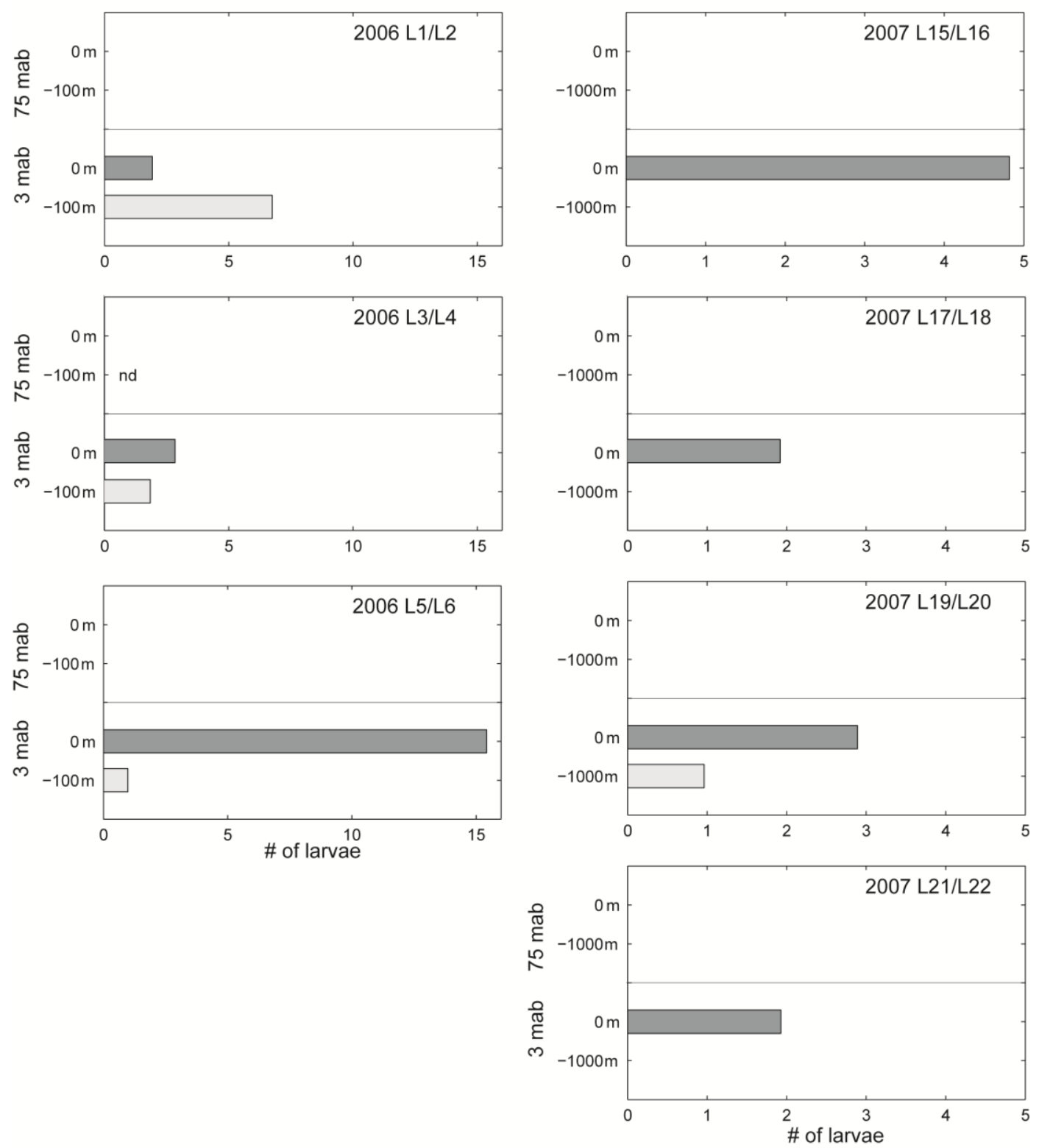

Supplementary Fig. S3. Day-to-day variation in abundance (no. larvae per $40,000 \mathrm{~L}$ ) of Sutilizona theca (gastropod) larvae in pump samples at heights of $3 \mathrm{~m}$ and $75 \mathrm{~m}$ above bottom, on axis (dark bars) and off axis (light bars). Details as in Fig. S1. 
Chaetosphaerid
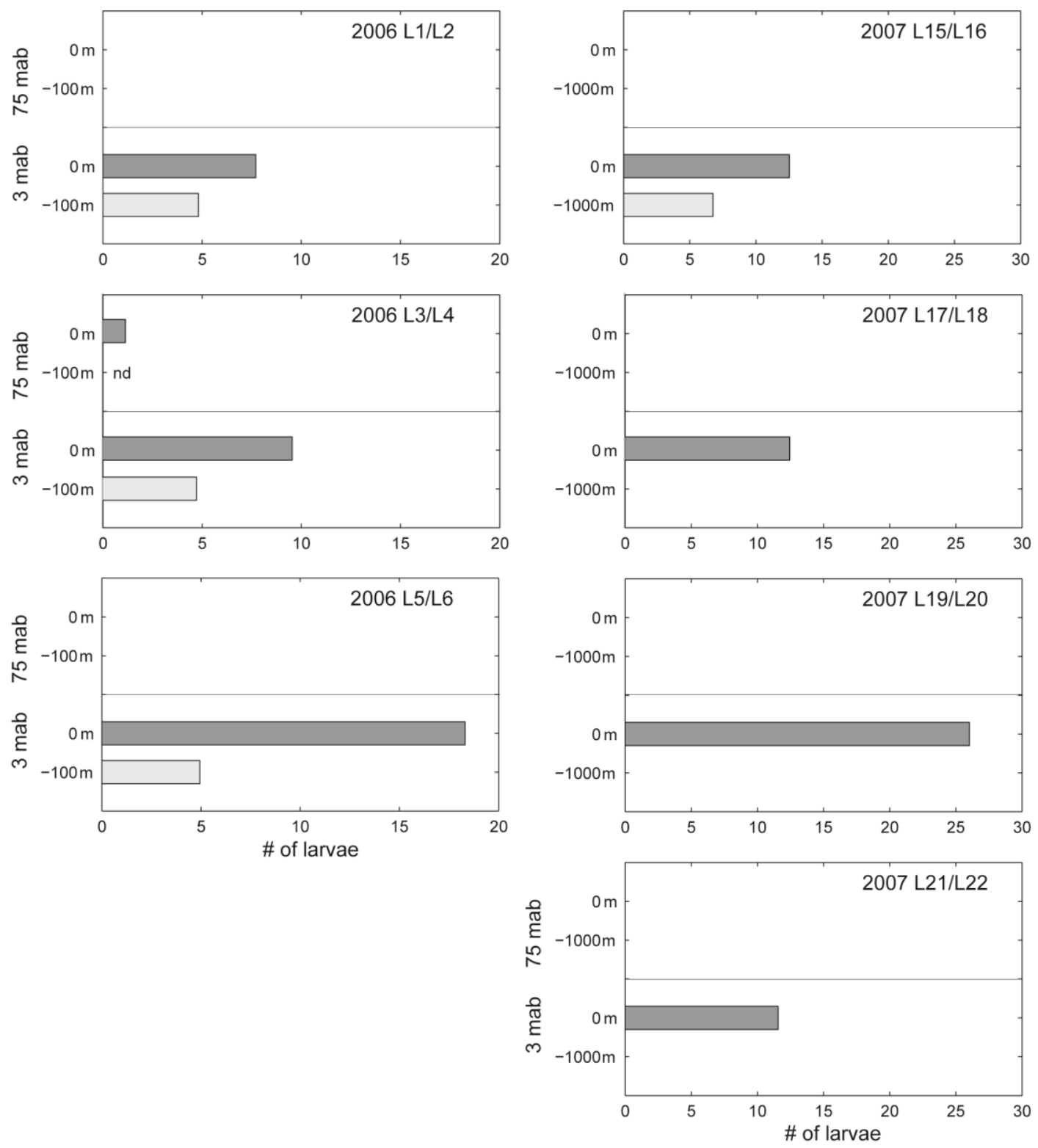

Supplementary Fig. S4. Day-to-day variation in abundance (no. larvae per $1000 \mathrm{~m}^{3}$ ) of chaetosphaerid (polychaete) larvae in pump samples at heights of $3 \mathrm{~m}$ and $75 \mathrm{~m}$ above bottom, on axis (dark bars) and off axis (light bars). Details as in Fig. S1. 


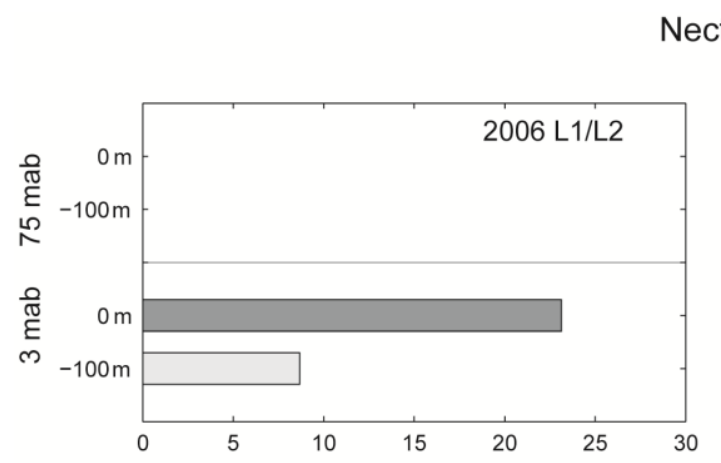

Nectochaete
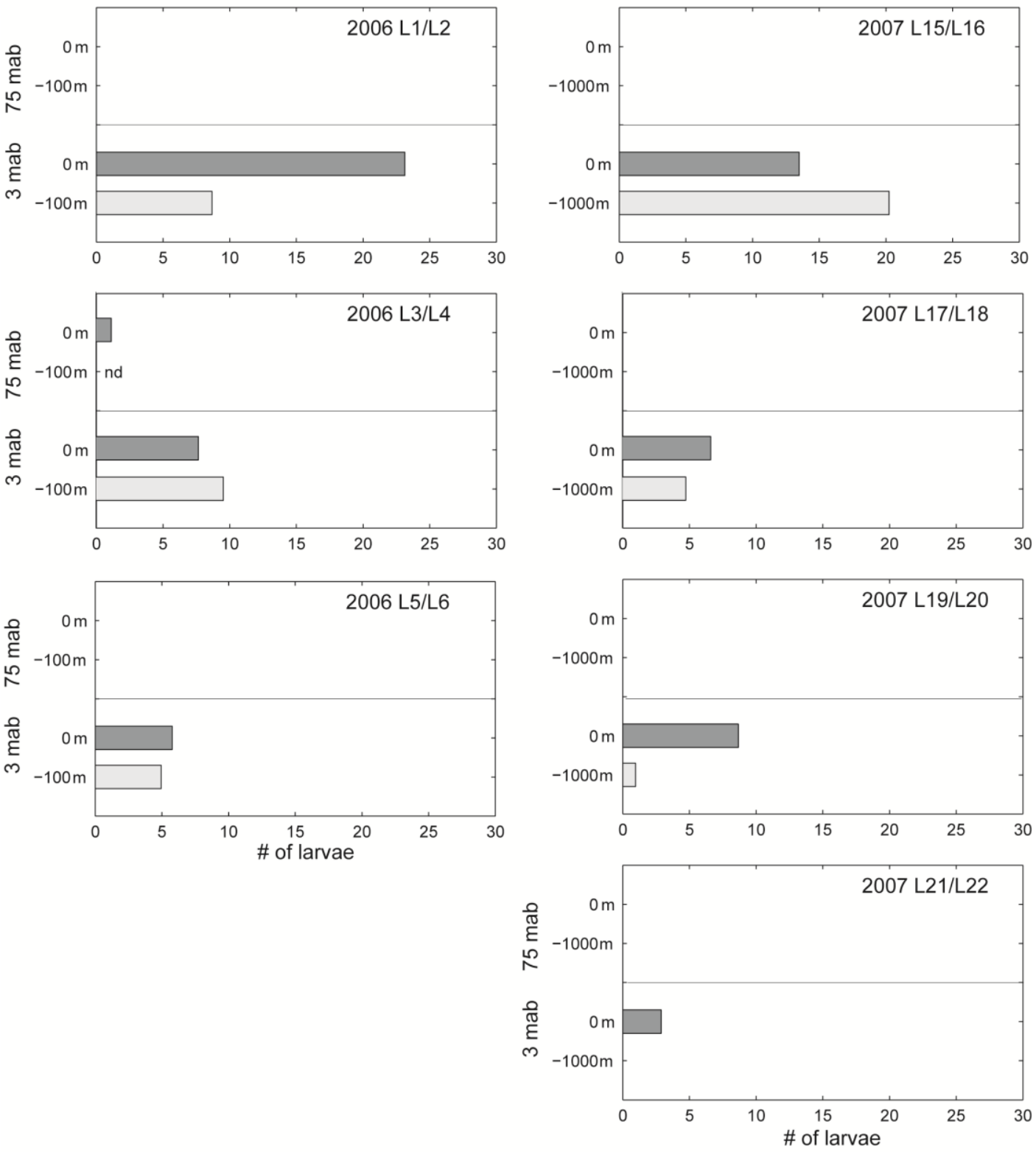

Supplementary Fig. S5. Day-to-day variation in abundance (no. larvae per $1000 \mathrm{~m}^{3}$ ) of nectochaete (polychaete) larvae in pump samples at heights of $3 \mathrm{~m}$ and $75 \mathrm{~m}$ above bottom, on axis (dark bars) and off axis (light bars). Details as in Fig. S1. 
Spionid
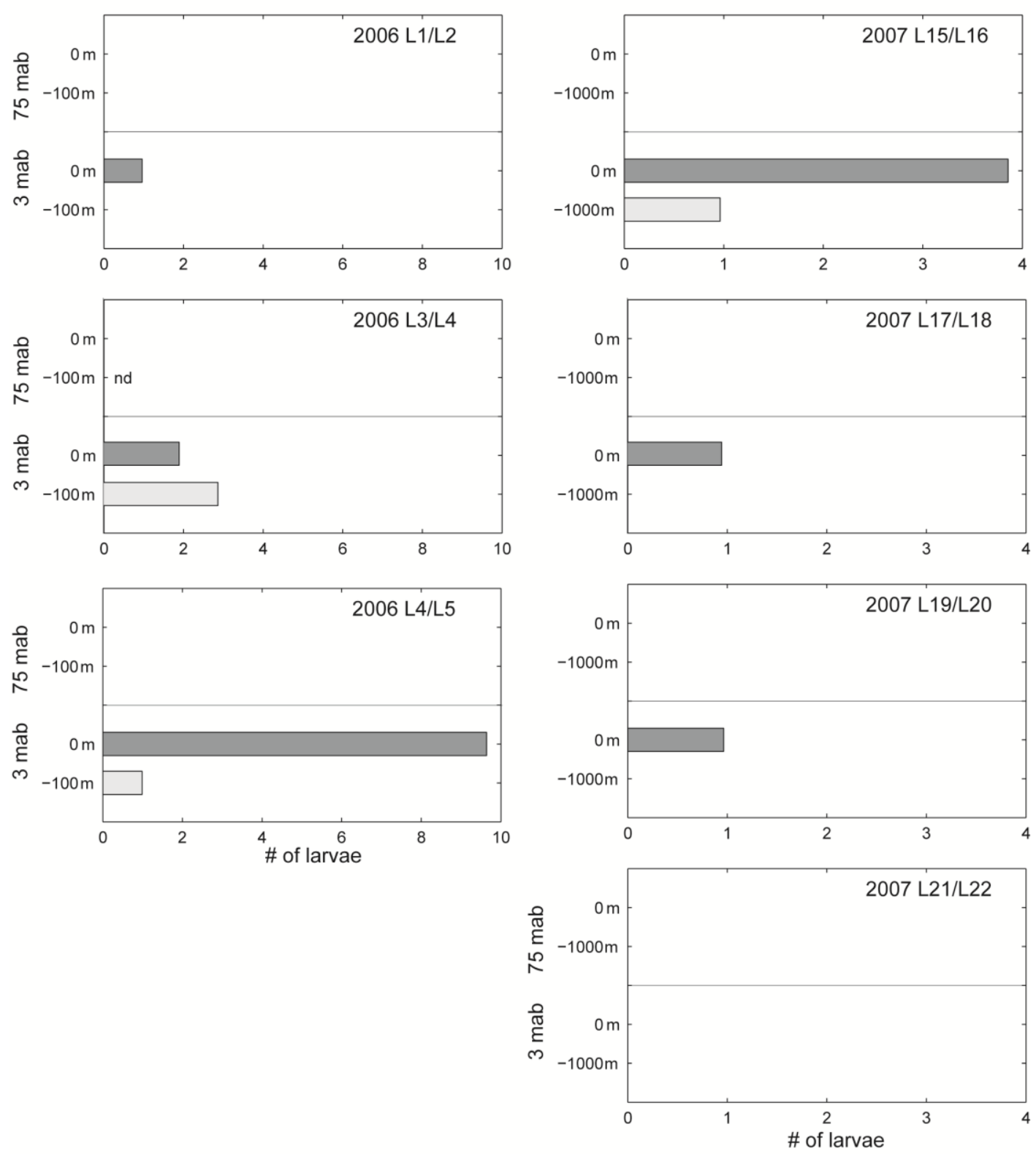

Supplementary Fig. S6. Day-to-day variation in abundance (no. larvae per $1000 \mathrm{~m}^{3}$ ) of spionid (polychaete) larvae and post-larvae in pump samples at heights of $3 \mathrm{~m}$ and $75 \mathrm{~m}$ above bottom, on axis (dark bars) and off axis (light bars). Details as in Fig. S1. 